\title{
Mega-mining and human rights in contemporary Mexico. 1982-2018
}

\author{
Federico Guzmán López ${ }^{1 *}$ \\ Guillermo Torres Carral ${ }^{2}$ \\ Gerardo Gómez González ${ }^{2}$
}

\begin{abstract}
The objective is to study mega-mining in Mexico, based on its contribution to domestic economic development with ecosocial impacts, along with the treatment of human rights that it generates in the communities. From political ecology and ecological economics, it is pertinent to analyze the territorial dispossession that causes conflicts between transnational private capital companies and communities for the right to natural commons gradually converted into merchandise. The question is: How does the process of attention to human rights originate in the mining industry and how does this phenomenon manifest itself? The hypothesis states that mega-mining practiced in Mexico by transnational private capital during the neoliberal development model, has generated supplies for other branches of the national economy, in exchange of violating human rights, and the involvement of Mexican communities surrounding mining megaprojects. Preliminary results indicate that mega-mining in Mexico is configured as a postcolonial enclave economy, where the extractive capital involved under the figure of Socially Responsible and Sustainable Enterprise is validated by a State policy of territorial dispossession that sacrificed half of the Mexican land and violated human rights.
\end{abstract}

Keywords: Human rights, territorial dispossession, ecological economy, socially responsible company,

mega-mining, Mexico.

\section{Megaminería y los derechos humanos en el México contemporáneo, 1982-2018}

\section{Resumen}

El objetivo de esta investigación consiste en estudiar la megaminería en México a partir de su contribución al desarrollo económico nacional con impactos eco-sociales, a la par del tratamiento a los derechos humanos que genera en esas comunidades. Desde la ecología política y la economía ecológica resulta pertinente analizar el despojo territorial que ocasionan conflictos entre empresas de capital privado transnacional y las comunidades por el derecho a los bienes comunes naturales, paulatinamente convertidos en mercancías. La pregunta es ¿Cómo se origina el proceso de atención a los derechos humanos por la industria minera y de qué manera se manifiesta dicho fenómeno? La hipótesis plantea que la megaminería practicada en México por el capital privado transnacional durante el modelo de desarrollo neoliberal ha generado suministros para otras ramas de la economía nacional a cambio de vulnerar los derechos humanos y la afectación de comunidades mexicanas aledañas a los megaproyectos mineros. Los resultados preliminares indican que la megaminería en México se configura en economía de enclave poscolonial, donde el capital extractivo, envuelto en la figura de empresa socialmente responsable y sustentable, está validado por una política de Estado de despojo territorial que sacrificaron la mitad del suelo mexicano y violaron los derechos humanos.

Palabras clave: Derechos humanos, despojo territorial, economía ecológica, empresa socialmente responsable, megaminería, México.

'Universidad Autónoma de Zacatecas. Doctorado en Ciencias Agrarias. Universidad Autónoma Chapingo,

carr. México-Texcoco, km 38.5, Chapingo, Texcoco Edo. de México. C. P. 56230.

2Universidad Autónoma Chapingo, Doctorado en Ciencias Agrarias. Universidad Autónoma Chapingo,

carr. México-Texcoco, km 38.5, Chapingo, Texcoco Edo. de México. C. P. 56230.

*Corresponding author: federic7@hotmail.com

Received: February 8, 2019

Accepted: December 11, 2019 


\section{Introduction}

The objective is to study mega-mining in Mexico from its contribution to the domestic economic development and its eco-social impacts, along with the violations to human rights it generates in the communities were it is carried out.

In the problem statement, it is shown that the Mexican State intervenes communities and receives a minimum portion of the mining lease in exchange of giving the private mining industry a main role in Mexican economy. Mainly to the one carried out by mega-mining, ${ }^{1}$ known as an exploitation and surface mining mineral refinement activity.

In the specific case of Mexico, the mining units have a processing capacity above two thousand tons per day.

The government's official narrative says that such industry is characterized by an increasing flow of transnational private capital, along with the jobs it creates. However, the contribution of mining on the exhaustion of natural resources and human rights vulnerability is not obvious in the government's speech.

This process has been more intense since 1994 when the North American Free Trade Agreement (NAFTA) entered into force as a mechanism of international commerce that legalized land dispossession of indigenous peoples through entrepreneurship of infrastructure megaprojects and plundering mainly of subsoil natural resources (groundwater, oil and minerals) and soil (biomass, fauna and superficial waters).

Before subscribing this agreement, Fundar (2017) mentioned:

Seoane (2013), defined mega-mining as:

"A specific capitalist exploitation of surface mining minerals which develops and becomes widespread during the last decades under the neoliberal hegemony.

Oriented towards the extraction of minerals scattered in low quantities in extended deposits; at the same time it entails a complex extraction and treatment process -with different toxic substances, e.g. through leaching with cyanide- of great volumes of dirt and rocks to finally obtain a minimum quantity of the sought mineral."

On the other hand, Wagner (2014) defines mega-mining as:

"A current mining form, also named large-scale metalliferous transnational mining, that is to say, a form of exploitation made by multinational enterprises that occupy large areas of land for its development. In addition, it is worth mentioning that mining enterprises use the placement of shares in the stock market or propaganda for investors and shareholders to get funds for their explorations and exploitations. These entrepreneurships are funded by the World Bank or the IMF."

\section{Introducción}

El objetivo consiste en estudiar la megaminería en México a partir de su contribución al desarrollo económico nacional y sus impactos eco-sociales, a la par de la violación de los derechos humanos que genera en las comunidades donde se desarrolla.

En el planteamiento del problema se pone de manifiesto que, el Estado mexicano interviene comunidades y recibe una mínima porción de la renta minera a cambio de otorgarle un papel preponderante a la industria minera privada en la economía mexicana. Principalmente a la que lleva a cabo la megaminería, entendida como una actividad de explotación y beneficio de minerales a cielo abierto.

Para el caso específico de México, se trata de unidades mineras con capacidad de procesamiento superior a las dos mil toneladas diarias.

Desde la narrativa oficial del gobierno se dice que dicha industria se caracteriza por un flujo creciente de inversión de capital privado transnacional, acompañado de los empleos que genera. Sin embargo, en el discurso del gobierno no se hace evidente la contribución minera al agotamiento de los recursos naturales y a la vulnerabilidad de los derechos humanos.

Este proceso ha ocurrido más intensamente desde el año 1994, cuando entró en vigor el Tratado de Libre Comercio de América del Norte (TLCAN), como mecanismo de comercio internacional que legalizó el despojo territorial de pueblos originarios mediante el emprendimiento de megaproyectos de infraestructura y saqueo de los recursos naturales del subsuelo principalmente (agua subterránea, petróleo y minerales) y del suelo (biomasa, fauna y aguas superficiales).

'En Seoane (2013:135) se definió megaminería como:

"Una particular explotación capitalista de minerales a cielo abierto que se desarrolla y generaliza en las últimas décadas bajo la hegemonía neoliberal. Orientada a la extracción de minerales que están dispersos en bajas cantidades en yacimientos extendidos; supone a su vez un complejo proceso de extracción y tratamiento-con diferentes sustancias tóxicas, por ejemplo, a través de la lixiviación con cianuro- de los enormes volúmenes de tierras y rocas obtenidos para conseguir finalmente una mínima cantidad del mineral buscado." Por su parte Wagner (2014), definió a la megaminería como:

"Una forma actual de minería, también denominada minería metalífera transnacional a gran escala, o sea, una explotación realizada por empresas multinacionales que ocupan enormes territorios para su desarrollo. Además, cabe destacar que las empresas mineras usan la colocación en el mercado de valores (bolsas de comercio) de títulos o bien la propaganda hacia inversores y accionistas para captar fondos para sus exploraciones y explotaciones. Estos emprendimientos están financiados por el Banco Mundial o el FMI." 
"the mining sector barely represented $0.72 \%$ of the Gross Domestic Product (GDP). After signing the NAFTA agreement a series of financial and fiscal measures took place which enabled investments from the United States and Canada in Mexico, especially from Canadian mining enterprises. Thus, nowadays, the mining sector represented about $4 \%$ of the GDP in 2016."

Research which study the mining industry as a developmental problem in Mexico, viewed in the international context of Latin America gives empirical data about water consumption and pollution in the region. Peña (2016) pointed out:

"The main usage of consumptive character corresponds to irrigated agriculture with an extraction equivalent to $70 \%$ of the total flow extracted. The second type of usage is the one made for household purposes and it reaches $19 \%$ of the total extracted. On the other hand, mining and industrial usage represent $11 \%$ of the total extraction. [...] Nowadays, industrial and mining pollution in Latin America and the Caribbean represent, after the one originated by household and agriculture activities an important source of pollution."

Emergence of progressive governments and social movements such as Movimiento de los Sin Tierra and the Movimiento Mesoamericano contra el modelo extractivo minero among others, made a contribution to the new correlation of forces of political power, with effects on social dynamics and the productive matrix that helped concretize constitutional reforms restricting economic, social and cultural rights

However, these reforms did not translate into policies and programs, Svampa (2017) pointed out: ... consensus of Commodities brought as a consequence the explosion of socio-environmental conflicts and the beginning of a new cycle of violation of human rights...

Meanwhile, for Mexico, the answer is being given by some of the collectives that have performed acts of resistance against mining megaprojects, such as Red Mexicana de Afectados por la Minería (REMA) and the Asamblea Nacional de Afectados Ambientales, both with nationwide presence in most federal entities. As well as other local civil society organizations, such as Frente Amplio Opositor a Minera San Xavier in the state of San Luis Potosi;
En Fundar (2017), se mencionó que antes de que se suscribiera dicho tratado:

"el sector minero apenas representaba $0.72 \%$ del Producto Interno Bruto (PIB). Posteriormente, a la firma del TLCAN tuvieron lugar una serie de medidas económicas y fiscales que facilitaron las inversiones de Estados Unidos y Canadá en México, particularmente de las empresas mineras canadienses. De tal forma que, actualmente, el sector minero representó alrededor de 4 \% del PIB en 2016."

Las investigaciones que estudian la industria minera como un problema de desarrollo en México, visto en el contexto internacional de América Latina, ofrece datos empíricos sobre consumo de agua y contaminación de la región, Peña (2016) puntualizó:

"El principal uso de carácter consuntivo corresponde a la agricultura de riego, con extracciones que equivalen a un $70 \%$ del caudal total extraído. El segundo tipo de aprovechamiento es el que se realiza para fines domésticos, y que alcanza el $19 \%$ del total. Por su parte, los usos mineros e industriales representan el $11 \%$ del total. [...] En la actualidad, la contaminación industrial y minera en América Latina y El Caribe constituye, después de la de origen doméstico y agrícola, una importante fuente contaminante."

El surgimiento de gobiernos progresistas y movimientos sociales como el Movimiento de los Sin Tierra y el Movimiento Mesoamericano contra el modelo extractivo minero, entre otros, contribuyeron a una nueva correlación de fuerzas del poder político, con efectos en la dinámica social y la matriz productiva, que permitió concretar reformas constitucionales limitando los derechos económicos, sociales y culturales.

Sin embargo, dichas reformas no se tradujeron en políticas y programas, Svampa (2017) señaló: ...el Consenso de los Commodities trajo como consecuencia la explosión de conflictos socioambientales y el inicio de un nuevo ciclo de violación de derechos humanos...

Mientras que, para el caso mexicano, la respuesta la están dando algunos de los colectivos que han realizado acciones de resistencia ante megaproyectos mineros como son principalmente la Red Mexicana de Afectados por la Minería (REMA) y la Asamblea Nacional de Afectados Ambientales, ambos de alcance 
the Consejo Indígena por la Defensa del Territorio de Zacualpan, Colima; the Movimiento Morelense contra la Minería de Metales Preciosos, and the Frente de Comunidades Afectadas por la Minería en la región norte del estado de Zacatecas, (Guzmán, 2018a).

In Mexico, contributions by Cortes (2008) were incorporated to the study of the nexus between mega-mining, human rights and development, ${ }^{2}$ understood as a social construction that contributes to the improvement of the population's quality of life in a territory, with the analysis of criminalization of social protest against those who defend social and economic rights. It refers to the mechanism implemented by the Mexican State in favor of extractive megaprojects including mega-mining.

Garibay and Balzaretti (2009) put forward the concept of negative reciprocity, represented with empirical information from the case of the Canadian transnational mine Goldcorp in communities in Guerrero, Mexico.

At the same time, Garibay (2010) argued about the mining accumulation process through peasant dispossession based on the experience of Goldcorp in Mezcala, Guerrero and Mazapil, Zacatecas, he referred to the

"accumulation of big volumes of capital for the benefit of global mining corporations, at the expense of denying land rights of peasant societies,

[...] for every thousand dollars of minerals extracted and sold, the corporation takes 999.82 and the communities only receive, 18 cents!"

In Gutierrez (2010), the destruction of social and economic rights generated by structural reforms implemented in the 1990's was highlighted, stressing on the modification made to Article 27 of the Constitution, Agrarian Laws, of National Waters, of Foreign Investments and the Mining Law, through which most state enterprises were put in the hands of private capital and afterwards the implementation of NAFTA .

\footnotetext{
${ }^{2}$ The concept of development within the neoliberal framework is mainly associated with the idea of progress when conditions to generate economic growth are established in a country through investment flow and creation of jobs. However, under this logic, topics regarding social inequality, human security and social peace are left unattended. That is why, in regard to development in Mexico's case, Ruiz (2019) stated, the Mexican State should stay in line to guarantee economic growth and social well-being through a national program that eradicates unequal economy and socio environmental impacts
}

nacional con presencia en la mayoría de las entidades federativas. Así como otras organizaciones civiles de alcance local como el Frente Amplio Opositor a Minera San Xavier, en el estado de San Luis Potosí; el Consejo Indígena por la Defensa del Territorio de Zacualpan, Colima; el Movimiento Morelense contra la Minería de Metales Preciosos, y el Frente de Comunidades Afectadas por la Minería en la región norte del estado de Zacatecas, (Guzmán, 2018a).

En México al estudio del nexo megaminería, derechos humanos y desarrollo, ${ }^{2}$ entendido como una construcción social que contribuye a mejorar la calidad de vida de la población en un territorio, le abonaron los aportes de Cortés (2008), con el análisis de la criminalización de la protesta social ante quienes defienden derechos sociales y económicos. Se refiere al mecanismo que implementa el Estado mexicano a favor de los megaproyectos extractivos incluida la megaminería.

Por su parte, Garibay y Balzaretti (2009) adelantaron el concepto de reciprocidad negativa, representado con información empírica del caso de la minera transnacional canadiense Goldcorp en comunidades de Guerrero, México.

Asimismo, Garibay (2010) con la experiencia de Goldcorp en Mezcala, Guerrero y Mazapil, Zacatecas, argumentó el proceso de acumulación minera por desposesión campesina al referirse a la:

"acumulación de grandes volúmenes de capital en beneficio de las corporaciones mineras globales, a costa de la negación de derechos territoriales de sociedades campesinas, [...] por cada mil dólares de mineral extraído y vendido la corporación toma 999.82 y las comunidades reciben solo j18 centavos de dólar!"

En Gutiérrez (2010), se destacó la destrucción de los derechos sociales y económicos que generaron las reformas estructurales implantadas en la década de 1990, destacando la modificación al Artículo 27

${ }^{2}$ Sobre el concepto desarrollo, que en el marco del modelo neoliberal se asocia principalmente con la idea de progreso, cuando se establecen las condiciones para generar crecimiento económico en un país mediante el flujo de inversiones y la creación de empleos. Sin embargo, bajo esa lógica se desatiende el tema de la desigualdad social, la seguridad humana y la paz social. Por ello, lo que planteó Ruiz (2019) sobre el desarrollo para el caso de México, es que el Estado mexicano debería mantenerse en la línea de garantizar el crecimiento económico y el bienestar social mediante un proyecto nacional que erradique la desigualdad económica y los impactos socioambientales. 
Furthermore, Patiño, Espinoza, \& García (2012) highlighted the communities' disadvantage against transnational mining enterprises, in the negotiation mechanisms for temporary occupation of land and distribution of the mining rent.

Cárdenas (2013), argues that mega-mining is considered as a dispossession of the nation because of the environmental, social and economic problems it generates, mainly in the communities where they establish their extractive megaprojects.

In Tetreault (2013), water pollution and overexploitation of superficial and subterranean sources of water by the mining industry was questioned. This phenomenon is conceived as a water footprint by Santacruz and Peña (2013). It also generates solid residues exposed in surface mining and artificial hills with toxic substances that pollute soil, water and air; this destroys local subsistence economy and social reproduction of indigenous peoples.

For Machado (2014), the mining industry is also responsible of giving hope for modernity through the conservation or restauration of the rural landscape of indigenous people who accommodate mining megaprojects, along with highlighting the socially responsible and sustainable company label. This is materialized with donations made by mining enterprises for the benefit of communities and the alleged environmental benefits they publish.

Even though mechanisms of violence occur simultaneously, where mega-mining represses all collective resistance action, it controls forms of association and restricts freedom.

Furthermore, Toledo (2015) highlighted the destruction of ecosystems and natural resources depletion by mining enterprises of transnational private capital, with direct consequences on human rights of a growing amount of Mexican rural communities.

About the analysis regarding the violation to human rights by transnational enterprises of private capital, Torres (2015) warned that:

"human rights are part of the rights by nature, therefore, cannot contravene, but must be consistent with one another. [...] Extractivism (mining, oil, gas, hydroelectric plant) reveals its most destructive
Constitucional, a las Leyes Agraria, de Aguas Nacionales, de Inversiones Extranjeras y la Ley Minera, a través de las cuales se puso en manos del capital privado la mayoría de las empresas estatales y posteriormente la puesta en marcha delTLCAN.

Asimismo, Patiño, Espinoza, \& García (2012) destacaron la desventaja que enfrentan las comunidades ante las empresas mineras transnacionales, en los mecanismos de negociación para la ocupación temporal de tierras y reparto de la renta minera.

En Cárdenas (2013), se argumentó que la megaminería es considerada como un despojo de la nación por los problemas ambientales, sociales y económicos que genera, principalmente en los territorios de las comunidades donde instalan sus megaproyectos extractivos.

En Tetreault (2013), se cuestionó que la industria minera contamina el agua y sobreexplota las fuentes de agua superficial y subterránea. Dicho fenómeno Santacruz y Peña (2013), lo conciben como huella hídrica. Además, genera residuos sólidos expuestos en tajos abiertos y cerros artificiales con sustancias tóxicas que contaminan el suelo, el agua y el aire; lo que destruye la economía local de subsistencia y la reproducción social de los pueblos originarios.

Para el investigador Machado (2014), a la industria minera también se le atribuye la esperanza de la modernidad a través de la conservación o restauración del paisaje rural de los pueblos originarios que albergan los megaproyectos mineros, aunado a destacar los distintivos de empresa socialmente responsable y sustentable. Lo anterior, se materializa con los donativos que realizan las empresas mineras en beneficio de las comunidades y por los supuestos beneficios ambientales que publicitan.

Aunque simultáneamente ocurren mecanismos de violencia, donde la megaminería reprime toda acción colectiva de resistencia, controla las formas de asociación y restringe las libertades.

Asimismo, Toledo (2015) destacó la destrucción del ecosistema y el agotamiento de los recursos naturales por empresas mineras de capital privado transnacional, con consecuencias directas para los derechos humanos de una cantidad cada vez mayor de comunidades rurales mexicanas. 
character by plundering and polluting territories and the whole planet. This wealth must not be wasted, instead, a minimum amount must be consumed so it can last as much as possible (this is a basic principle of ecologic political economy)."

CNDH (2016) warned about 150 thousand people, victims of internal forced displacement in Mexico, associated to what Azamar (2016) postulated as commodification of human rights, mechanisms that could increase in the next few years because of the expansion of the mining industry. Mainly because according to Geocomunes (2017), in the Mexican territory, there were 24 thousand 506 mining concession titles in force during 2015.

Bellota (2017) also addresses the destructive role of mega-mining in the rights of indigenous and rural communities, disrupting their traditions and their relation with nature. Such is the case of the Huicholes in Wirikuta territory by infringing self-determination of the indigenous peoples which enables them to decide freely about the territory.

To contribute to the explanation of this phenomenon Guzmán (2018a and 2018b) proposed the concept mining accumulation by human right extraction. Additionally, Lemus (2018) pointed out: vulnerability of the freedom and security of the community members, as part of the dispossession process of the treasures ripped off from the subsoil and soil that form part of Mexico's natural wealth.

Tetreault, McCulligh, \& Carlos (2019) pointed out two cases of collective acts of resistance against mining projects in the state of San Luis Potosi. One was made by the Huichol indigenous community in defense of the sacred Wirikuta territory against First Magic Silver. The other one was made against the mining unit San Xavier "because the Canadian enterprise New Gold is still exploiting at less than 20 kilometers from the capital of the state of San Luis Potosi, even though the Frente Amplio Opositor a la Minera San Xavier has won legal protection to stop the project."

Studies made in Mexico helped identify central features of the mining strategy of the Mexican government. They were also used to theoretically outline nexus between mega-mining, human rights and resistance through elements of political ecology and ecological economics along with
Sobre el análisis de violación de los derechos humanos por empresas de capital privado transnacional, Torres (2015) advirtió que:

"los derechos humanos son una parte de los derechos de la naturaleza, por lo que no pueden contravenirse, sino más bien ser compatibles.

[...] El extractivismo (minería, petróleo, gas, hidroeléctricas) revela su carácter más destructivo al saquear y contaminar territorios y el planeta entero. Esta riqueza no debe dilapidarse sino consumirse lo mínimo para que dure lo máximo posible (este es un principio básico de economía política ecológica)."

La CNDH (2016) advirtió sobre 150 mil personas víctimas de desplazamiento forzado interno en México, asociado a lo que Azamar (2016), postuló como la mercantilización de los derechos humanos, mecanismo que podría aumentar en los próximos años ante la expansión de la industria minera. Principalmente porque de acuerdo con Geocomunes (2017), en el territorio mexicano se tenían vigentes 25 mil 506 títulos de concesión minera durante el año 2015.

También Bellota (2017), abordó el papel destructivo de la megaminería en los derechos indígenas y las comunidades rurales, trastocando sus costumbres y su relación con la naturaleza. Como el caso de los huicholes en territorio de Wirikuta, al vulnerar la autodeterminación de los pueblos que les permita decidir libremente sobre el territorio.

Para contribuir a la explicación de dicho fenómeno Guzmán (2018a y 2018b) propuso el concepto acumulación minera por extracción de derechos humanos. Asimismo, Lemus (2018) señaló: la vulnerabilidad de la libertad y la seguridad de los integrantes de las comunidades, como parte del proceso de despojo de los tesoros arrancados del subsuelo y suelo que conforman la riqueza natural nacional.

Tetreault, McCulligh, \& Carlos (2019) señalaron dos casos de acciones colectivas de resistencia contra proyectos mineros en el estado de San Luis Potosí. Uno fue por la comunidad indígena huichol en defensa del territorio sagrado de Wirikuta contra First Majestic Silver. El otro en oposición a la unidad minera San Xavier "porque dicha compañía canadiense New Gold sigue explotando a menos de 20 kilómetros de la capital del estado de San Luis Potosí, a pesar de que el Frente Amplio Opositor a la Minera San Xavier ha ganado amparos para detener el proyecto." 
empirical data, mainly those which highlighted the extractivism model, territorial dispossession, pollution and socio-environmental conflicts.

The question is, how does the process of attention to human rights from the mining industry begin and how does this phenomenon manifest?

The hypothesis states that mega-mining practiced in Mexico during the neoliberal period, mainly benefits transnational private capital enterprises dedicated to export minerals and whose profits are transferred to other enterprises located in developed economies such as Canada, as to the owners of big Mexican mining corporations. All of the above in exchange of violating human rights and promoting the destruction of Mexican communities neighboring mining megaprojects.

Regarding physical conditions of the area under study, Mexico is located in the North American region, bordering the United States to the north and Guatemala and Belize to the south. The Mexican territory has a surface area of one million 964 thousand 375 square kilometers; it is divided into 32 federal entities, where 123 million 982528 inhabitants live in (Instituto Nacional de Estadística y Geografía, 2018a); from which $43.6 \%$ equivalent to 53.4 million Mexicans live in poverty. (Consejo Nacional de Evaluación de la Política de Desarrollo Social, 2016).

Mexico is settled in a wealthy territory and with diverse mineral resources, which made it a mining enclave that transferred a surplus to the Spanish Crown for five centuries.

However, during the 36 years of the neoliberal period in contemporary Mexico, privatization of the territory and plundering of natural resources were intensified, expressed in a considerable increase of concessions given to mega-mining and direct foreign investment destined to the sector, with a direct impact on depletion and pollution of natural resources.

This process is legally protected by Article 27 of the Constitution and Article 15 of the Mining Law which allows granting mining concessions for a 50 year period, with the possibility to extend this right for another 50 years.

This legal basis allowed the privatization of 113.3 million hectares in March, 2016, equivalent to $57.6 \%$ of the national territory during the period of 1982-2016.

This research is shown in four sections: the first one offers materials and methods with details about the
Los estudios realizados en México permitieron identificar los rasgos centrales de la estrategia minera del gobierno mexicano. También dieron la posibilidad de esbozar teóricamente sobre el nexo megaminería, derechos humanos y resistencias, mediante elementos de la ecología política y la economía ecológica; acompañados con datos empíricos, principalmente aquéllos que resaltaron el modelo extractivista, el despojo territorial, la contaminación y los conflictos socioambientales.

La pregunta es ¿Cómo se origina el proceso de atención a los derechos humanos por la industria minera y de qué manera se manifiesta dicho fenómeno?

La hipótesis plantea que la megaminería practicada en México durante el periodo neoliberal beneficia principalmente a las empresas de capital privado transnacional, dedicadas a la exportación de minerales y cuyas utilidades se transfieren a empresas cuya sede se ubica en las economías desarrolladas como Canadá, así como a los propietarios de los grandes corporativos mineros mexicanos. Todo lo anterior, a cambio de vulnerar los derechos humanos y fomentar la destrucción de comunidades mexicanas aledañas a los megaproyectos mineros.

En cuanto a las condiciones materiales del área de estudio destaca que, México se localiza en la región de América del Norte, colindando al norte con Estados Unidos de América y al sur con Guatemala y Belice. El territorio mexicano cuenta con una superficie de un millón 964 mil 375 kilómetros cuadrados; está dividido en 32 entidades federativas, en los que habitan 123 millones 982 mil 528 habitantes (Instituto Nacional de Estadística y Geografía, 2018a); de los cuales, 43.6 $\%$ equivalente a 53.4 millones de mexicanos viven en situación de pobreza (Consejo Nacional de Evaluación de la Política de Desarrollo Social, 2016).

México se encuentra asentado en un territorio rico y variado de recursos minerales, lo que le permitió ser un enclave minero que transfería excedente a la Corona española desde hace cinco siglos.

Sin embargo, en el México contemporáneo durante los 36 años del periodo neoliberal fue cuando se agudizó la privatización del territorio y la rapiña de los recursos naturales, expresado en aumentos considerables de la superficie concesionada a la megaminería y a la inversión extranjera directa destinada a dicho sector, con incidencia directa en 
research technique used and the empirical evidence gathered. The second one shows the role of the mining industry in Mexico's economic development.

The third one outlines an explanation of megamining effects on human rights considered in the Universal Declaration of Human Rights, the International Covenant on Civil and Political rights and the International Covenant on Economic, Social and Cultural Rights, which integrate the International Bill of Human Rights.

The fourth one presents some elements to design policies, programs and projects about mega-mining with a human rights perspective in the sociopolitical framework of the current political transformation in Mexico.

\section{Materials and Methods}

Indirect observation was used as the research technique to offer an exploratory outlook indicative of nexus between mega-mining, human rights and development in Mexico.

For this purpose, documents with theoretical information about extractivism and mega-mining with a human rights approach were reviewed. This allowed us to have the historiography of the main researchers and their contributions about the topic mentioned above.

Economic, legal, administrative and testimonial empirical evidence associated with the mining industry in Mexico was also gathered, it was obtained from public federal institutions such as the Cámara de Diputados del Congreso de la Unión, the Instituto Nacional de Estadística y Geografía, the Secretaría de Economía, the Servicio Geológico Mexicano, the Secretaría de Desarrollo Agrario, Territorial y Urbano, the Secretaría de Trabajo y Previsión Social, the Comisión Nacional de los Derechos Humanos and the Consejo Nacional de Evaluación de la Política de Desarrollo Social.

Data from national and international business and civil society organizations were gathered, among which Cámara Minera de México, Red Mexicana de Afectados por la Minería, Geocomunes, Parametría, Fundar, Observatorio de Conflictos Mineros de América Latina and Environmental Justice Organisations, Liabilities and Trade stand out. el agotamiento y contaminación de los recursos naturales.

Dicho proceso está amparado legalmente por lo dispuesto en el Artículo 27 Constitucional y el Artículo 15 de la Ley Minera, que permite el otorgamiento de concesiones mineras por un periodo de 50 años, con la posibilidad de ejercer el derecho de prórroga por otros 50 años.

La base legal mencionada permitió en el mes de marzo de 2016 la privatización de 113.3 millones de hectáreas, equivalente al $57.6 \%$ del territorio nacional durante el periodo 1982-2016.

Esta investigación se presenta en cuatro secciones: la primera, ofrece los materiales y métodos con los detalles acerca de la técnica de investigación utilizada y la evidencia empírica recabada. La segunda, muestra el papel de la industria minera en el desarrollo económico de México.

La tercera, permite esbozar una explicación de las afectaciones de la megaminería a los derechos humanos contemplados en la Declaración Universal de Derechos Humanos, el Pacto Internacional de Derechos Civiles y Políticos, y el Pacto Internacional de Derechos Económicos, Sociales y Culturales, que en conjunto integran la Carta Internacional de Derechos Humanos.

Y la cuarta, presenta algunos elementos para el diseño de políticas, programas y proyectos sobre megaminería con perspectiva de derechos humanos en el marco sociopolítico de la actual transformación política de México.

\section{Materiales y métodos}

La técnica de investigación utilizada fue la observación indirecta para ofrecer un panorama exploratorio indicativo sobre el nexo megaminería, derechos humanos y desarrollo en México.

Para ello, se revisaron documentos que integran información teórica acerca de los estudios sobre extractivismo y megaminería con enfoque de derechos humanos. Lo que permitió contar con la historiografía en cuanto a los principales investigadores y sus aportes sobre la temática antes señalada.

Asimismo, se recabó evidencia empírica de tipo económica, legal, administrativa y testimonial, relacionada con la industria minera en México, misma que fue obtenida de instituciones públicas 
Different sources from newspapers and magazines were taken into consideration, mainly from the national press, among which El Economista, La Jornada, Revista Proceso and Contralínea stand out.

The consulted documents were selected under the time criteria corresponding from 1982 to 2018, so the information provided could illustrate what happened in Mexico regarding mega-mining and human rights during the neoliberal period, emphasizing on those cases where community resistance has signified a change in favor of the affected communities, mainly by being declared as mining free territories.

It was also taken into consideration that the reviewed sources were framed within the thinking of the critical studies of development to show the impact of the mining industry on human rights.

Two dimensions were analyzed: economic and social. In the economic dimension, the category of mining industry was analyzed from the behavior of economic data added at a domestic level related with the internal market and foreign trade: Gross Domestic Product (GDP), employment, direct foreign investment, direct domestic investment, mining rights and taxes and mining lease.

In the social dimension, human rights were analyzed from four categories: civil rights, political rights, economic, social and cultural rights, and solidarity or indigenous peoples rights ${ }^{3}$. For which a map was made of the eco-social problems caused by transnational mining enterprises installed in Mexico from what was established in the Universal Declaration of Human Rights, the International Covenant on Civil and Political Rights, and the International Covenant on Economic, Social and Cultural Rights. Different international treaties, conventions and protocols on human rights were considered, which address women and children's human rights as well as reproductive and sexual

${ }^{3}$ According to Bailón (w/d) human rights categories are classified in four generations: civil rights as first generation human rights, political rights as second generation human rights, social, economic and cultural rights as third generation human rights and solidarity or indigenous peoples rights as fourth generation human rights. This classification gives insight to new claims from the society such as the right for development, peace, a healthy environment, reproduction and public information. federales como la Cámara de Diputados del Congreso de la Unión, el Instituto Nacional de Estadística y Geografía, la Secretaría de Economía, el Servicio Geológico Mexicano, la Secretaría de Desarrollo Agrario, Territorial y Urbano, la Secretaría de Trabajo y Previsión Social, la Comisión Nacional de los Derechos Humanos y el Consejo Nacional de Evaluación de la Política de Desarrollo Social.

Se recopilaron datos de organizaciones empresariales y de la sociedad civil, nacionales e internacionales entre las que destaca la Cámara Minera de México, la Red Mexicana de Afectados por la Minería, Geocomunes, Parametría, Fundar, el Observatorio de Conflictos Mineros de América Latina y Environmental Justice Organisations, Liabilities and Trade.

También se consideraron diversas fuentes hemerográficas, principalmente de la prensa nacional, entre los que destacan los periódicos: El Economista, La Jornada, Revista Proceso y Contralínea.

Los documentos consultados fueron seleccionados bajo el criterio temporal correspondiente a los años de 1982-2018, para que brindaran información que permitiera dar cuenta de lo que ocurrió en México sobre la megaminería y los derechos humanos durante el periodo neoliberal, con énfasis en aquellos casos en los que las resistencias comunitarias han significado cambios a favor de las comunidades afectadas, principalmente por declararse territorios libres de minería.

También se consideró que la mayoría de las fuentes de información consultadas estuvieran enmarcadas dentro del pensamiento de los estudios críticos del desarrollo para mostrar los impactos de la industria minera en los derechos humanos.

Se analizaron dos dimensiones: la económica y la social. En la económica se analizó la categoría industria minera, a partir del comportamiento de datos económicos agregados a nivel nacional relacionados con el mercado interno y el comercio exterior: Producto Interno Bruto (PIB), empleo, inversión extranjera directa, inversión nacional directa, derechos mineros e impuestos y renta minera.

En la dimensión social se analizaron los derechos humanos a partir de cuatro categorías: derechos civiles, derechos políticos, derechos económicos, sociales y culturales $y$, los derechos de solidaridad 
health rights, and the right to have access to public information.

\section{Results and discussion}

The role of the mining industry in Mexico's economic development

Unlike the current neoliberal stage in Mexican mega-mining, the previous stage, from 1961 to 1979 according to Burnes (2006), nationalization of this extractive industry counted with the participation of actors from the Mexican public and private enterprises integrated to productive chains.

While the subsequent neoliberal period, from the 1980s to the first two decades of the 21st century has been characterized by denationalization of Mexican mining and dominance of transnational enterprises.

Large-scale mining practiced in Mexico corresponds to a neoliberal exploitation model of the territory based on the extraction of metallic minerals by appropriation and dispossession of territory. The foregoing is generated by access mechanisms to lands where mining enterprises operate (lease, buying and selling, expropriation, constitutional easement and temporary occupation). The communities are forced under expropriation threat, protected by the 1992 Mining Law under the 50 year temporary occupational act, extendable for an equivalent amount of years.

Labor overexploitation is also distinguished, especially because for 2013 according to Casado and Sánchez (2019) "Hegemony in the great silver, copper and gold mining enterprise place outsourcing between 65 and $70 \%$ of the jobs they create". Additionally, the few jobs created for peasants from communities neighboring the mining companies are the least specialized, they earn the lowest wages and do the tasks with high occupational risk.

Furthermore, the irreversible impact the mining industry has on the environment is seen initially on the generation of toxic wastes. According to Guzmán (2018a), during 2014, for the exploitation of five metallic minerals: gold, silver, copper, lead and zinc, 10 $748^{\prime} 130721.7$ tons of waste rock were generated.

According to Harvey (2004), large-scale mining is framed in a process that started as accumulation o de los pueblos. ${ }^{3}$ Para lo cual se generó un mapeo de problemas eco-sociales ocasionados por parte de las empresas mineras transnacionales instaladas en México a partir de lo establecido en la Declaración Universal de Derechos Humanos, el Pacto Internacional de Derechos Civiles y Políticos y el Pacto Internacional de Derechos Económicos, Sociales y Culturales. También se consideraron diversos tratados, convenciones y protocolos internacionales de derechos humanos, que abordan derechos de las mujeres y los niños, así como los derechos reproductivos y salud sexual, y el derecho de acceso a la información pública.

\section{Resultados y discusión}

\section{El papel de la industria minera en el desarrollo}

económico de México

A diferencia de la actual etapa neoliberal en la minería mexicana, la etapa previa de 1961 a 1979 según Burnes (2006), la nacionalización de esta industria extractiva contaba con la participación de actores de empresas públicas y privadas mexicanas integradas a las cadenas productivas.

Mientras que el periodo neoliberal posterior, desde la década de 1980 hasta estas dos primeras décadas del siglo $X X I$, se ha caracterizado por la desnacionalización de la minería mexicana y el dominio de empresas transnacionales.

La minería a gran escala practicada en México corresponde a un modelo de explotación neoliberal del territorio basado en la extracción de los minerales metálicos a partir de la apropiación y despojo territorial. Lo anterior se genera por los mecanismos de acceso a las tierras donde operan las empresas mineras (alquiler, compra-venta, expropiación, constitución de servidumbre y ocupación temporal). Se fuerza a las comunidades bajo amenaza de expropiación, amparados en la Ley Minera de 1992,

${ }^{3}$ De acuerdo con Bailón (s/f) las categorías de derechos humanos se clasificaron en cuatro generaciones: los derechos civiles como derechos humanos de primera generación, los derechos políticos como derechos humanos de segunda generación, los derechos sociales, económicos y culturales como derechos humanos de tercera generación y los derechos de solidaridad o de los pueblos como derechos humanos de cuarta... ${ }^{3}$ (cont.)...generación. Dicha clasificación permite dar visibilidad a las nuevas reivindicaciones de la sociedad como el derecho al desarrollo, a la paz, al medio ambiente sano, a la reproducción y a la información pública. 
for dispossession ${ }^{4}$, and has degenerated in territorial plundering marked by looting natural wealth and destroying natural resources.

Transnational corporations of private capital compete for the territory and its mineral resources, they became the main actors of extraction and refinement of metallic minerals which exacerbated during the first 18 years of the $21^{1 \text { st }}$ century.

At a national level, the Servicio Geológico Mexicano (2018), pointed out that in Mexico, in addition to the presence of large transnational corporations owned by Mexican businessmen: Frisco, Peñoles and Grupo Mexico, 988 megaprojects are also in the hands of foreigners. From which, more than 80 $\%$ are controlled by their North American business partners: $65 \%$ are based in Canada and $16 \%$ in The United States of America and the rest are mainly in Australia, China, Japan, United Kingdom, South Korea, Chile, France, Spain and India.

In order to explain how the intervention of the mining industry has taken place in the Mexican economy, emphasizing on extraction and refinement of metallic minerals, seven traits are highlighted:

\section{1) Positions of Mexican mining at a global level.} The Servicio Geológico Mexicano (2018) mentions that Mexico has an important presence in activities related to metal mining because for mining exploration in Latin America alone, it receives $27 \%$ of the investments at a global level. Additionally, Mexico's participation ranks third in the region and seventh at a global scale with a $6 \%$ contribution.

In addition, Servicio Geológico Mexicano (2018) highlighted that:

"exports of metallic and non-metallic minerals registered a $5.67 \%$ increase in 2017, with regard to 2016. [...] Mexico is found within the 14 main producers of 22 minerals at a global level and it is the world leader in silver production, it occupies the prestigious second place on fluorite production, third on bismuth, celestite and wallostonite."

${ }^{4}$ Process directed towards keeping the neoliberal phase of the capitalist production system, "it includes commodification and privatization of the land and forced expulsion of peasant populations; conversion of different forms of rights to property-common, collective, state, etc.- in exclusive rights to property; suppression of the right to common goods. bajo la figura de ocupación temporal de 50 años, prorrogable a un periodo equivalente.

También le distingue la sobreexplotación del trabajo, sobre todo porque para 2013 según Casado y Sánchez (2019), "La hegemonía de la gran empresa en la minería de plata, cobre y oro hace que la subcontratación se sitúe entre 65 y $70 \%$ del empleo que generan". Aunado a lo anterior, los pocos empleos que se generan para los campesinos de las comunidades aledañas a las empresas mineras son los menos especializados, perciben los salarios más bajos y hacen tareas con altos riesgos laborales.

Asimismo, la industria minera implica impactos medioambientales irreversibles que, en primera instancia, se reflejan en la generación de desechos tóxicos. De acuerdo con Guzmán (2018a), durante el año 2014 para la explotación de cinco minerales metálicos: oro, plata, cobre, plomo y zinc se generaron $10748^{\prime} 130721.7$ toneladas de desechos de roca.

De acuerdo con Harvey (2004), la minería a gran escala se enmarca en un proceso que inició como acumulación por desposesión, ${ }^{4}$ que ha degenerado en el despojo territorial marcado por el saqueo de la riqueza natural y la destrucción de los recursos naturales.

Los corporativos de capital privado transnacional, que se disputan el territorio y los recursos minerales, se convirtieron en actores centrales de un proceso de extracción y beneficio de minerales metálicos que se agudizó durante los primeros 18 años del siglo XXI.

A nivel nacional el Servicio Geológico Mexicano (2018), señaló que en México además de la presencia de los tres grandes corporativos transnacionales propiedad de empresarios mexicanos: Frisco, Peñoles y Grupo México, también operan 988 megaproyectos en manos de extranjeros. De los cuales, más del $80 \%$ están controlados por sus socios comerciales de América del Norte: $65 \%$ tienen sede corporativa en Canadá y $16 \%$ en Estados Unidos de América y el resto principalmente en Australia, China, Japón, Reino Unido, Corea del Sur, Chile, Francia, España e India.

Para explicar cómo se ha dado la intervención de la industria minera en la economía mexicana

${ }^{4}$ Proceso encaminado a mantener la fase neoliberal del sistema de producción capitalista, "incluyen la mercantilización y privatización de la tierra y la expulsión forzosa de las poblaciones campesinas; la conversión de diversas formas de derechos de propiedad -común, colectiva, estatal, etc.- en derechos de propiedad exclusivos; la supresión del derecho a los bienes comunes". 
2) Contribution of mining to the national GDP. According to the Instituto Nacional de Estadística y Geografía (2018b) it was highlighted in the Sistema de Cuentas Nacionales, that secondary activities of the metallic and non-metallic minerals mining subsector have contributed with 3'151 418 million pesos, in 2013 prices, to the National GDP during the last 25 years, which go from 1993-2017, this number is equivalent to only $0.89 \%$ of the average National GDP, but globally, it contributed $8.49 \%$ to the global mining sector However, most of the $7.6 \%$ corresponds to oil and gas extraction, while the remaining $0.40 \%$ corresponds to services regarding the mining industry. This is a minor contribution of metallic minerals extractions to the macroeconomic activity of the country.

3) Employment in mining's secondary activity. According to the Secretaría de Economía (2018), mining employment numbers went from 262 574 in 2001 to 371556 people in 2017. The latter is equivalent to $0.68 \%$ of the 54027997 Mexicans who are part of the Occupied Economically Active Population (Secretaría del Trabajo y Previsión Social, 2018).

When checking the employment behavior in the mining-metallurgic industry per subsector, according to the Servicio Geológico Mexicano (2018), it was seen that from 371556 jobs in the mining sector for 2017, fabrication of nonmetallic mining products ranked first because it registered 142710 jobs, equivalent to $38.45 \%$; basic metallic industries ranked second with 112 751 jobs, equivalent to $30.3 \%$; extraction and refinement of metallic minerals ranked third with 75379 jobs, equivalent to $20.3 \%$; extraction and refinement of mineral carbon, graphite and other non-metallic minerals ranked fourth with 38564 jobs, equivalent to $10.4 \%$ and salt exploitation ranked fifth with 2152 jobs, equivalent to $0.6 \%$.

The previous data indicated that the extraction and refinement of metallic minerals contributed only with a fifth part of the total amount of jobs in the country's mining sector.

4) Articulation of transnational capital networks. The Mexican Stock Exchange, stock markets, poniendo énfasis en la extracción y beneficio de minerales metálicos, se destacan siete rasgos:

\section{1) Posiciones de la minería mexicana a nivel} mundial. El Servicio Geológico Mexicano (2018) indica que México tiene una presencia importante en las actividades relacionadas con la minería metálica, ya que, solamente para el rubro de exploración minera en América Latina, capta el $27 \%$ de inversión a nivel mundial. Además, México participa en este rubro en el tercer lugar de la región y, el séptimo a nivel global con un aporte del $6 \%$.

Asimismo, el Servicio Geológico Mexicano (2018) destacó:

"Las exportaciones de minerales metálicos y no metálicos registraron un incremento del $5.67 \%$ en el 2017, con respecto al 2016. [...] México se encuentra dentro de los 14 principales productores a nivel mundial de 22 minerales, y es líder mundial en la producción de plata, ocupa el prestigioso segundo lugar en la producción de fluorita, tercero en la producción de bismuto, celestita y wollastonita."

2) Aportación de minería al PIB Nacional. De acuerdo con el Instituto Nacional de Estadística y Geografía (2018b) en el Sistema de Cuentas Nacionales, se destacó que las actividades secundarias del subsector de la minería de minerales metálicos y no metálicos han contribuido con 3'151 418 millones de pesos a precios de 2013 al PIB Nacional durante los últimos 25 años, que abarcan el periodo 1993-2017, cifra que equivale solamente al $0.89 \%$ promedio anual del PIB Nacional, pero de manera global el sector de la minería le aportó el $8.49 \%$.

Sin embargo, la mayor parte $7.6 \%$ corresponde a la extracción de petróleo y gas, mientras que el $0.40 \%$ restante se refiere a servicios relacionados con la minería. Lo anterior, implica un aporte marginal de la extracción de minerales metálicos a la actividad macroeconómica del país.

3) Empleo en la actividad secundaria de la minería. De acuerdo con la Secretaría de Economía (2018), las cifras de empleo de la minería pasaron de 262574 en 2001 a 371556 personas en 2017. Último dato equivalente al $0.68 \%$ de los 54 027997 mexicanos que integran la Población 
banks, the supply network of machinery and technological services and mining corporations are some of the beneficiaries of the production value of mining-metallurgy of metallic minerals, which in the 2017 fiscal year increased up to 305.4 thousand million pesos and 269.6 thousand million pesos for non-metallic minerals, in total it added up to 575 thousand million pesos, equivalent to USD\$30 025.3 million dollars (Servicio Geológico Mexicano, 2018).

5) Private capital investment. According to the Secretaria de Economía (2015 y 2018) the previous number is above the USD\$27381.7 million dollars of direct foreign investment destined to mining, equivalent to $3.1 \%$ of the USD\$583 522.4 million dollars of the total direct foreign investment perceived in Mexico during the last 36 years from 1982-2018.

This indicates that the mining industry in Mexico is highly profitable, to the extent of perceiving, in only one year, a higher production value than the total foreign investment received for megamining during 36 years.

When comparing the origin of private capital investment in mega-mining, the national direct investment is the one that has played a more dynamic role because for the period between 2002-2017 it had an amount of USD\$53 209 million dollars, reaching an average per year of USD\$3 thousand 325.5 million dollars, practically more than doble the USD\$24 561 million dollars of direct foreign investment perceived for the same period, which in average per year were equivalent to USD\$1535 million dollars.

6) Distribution of the mining lease. However, from that amount of invested private resources, at the moment of recouping the capital and obtaining profits, the distribution of the mining lease is unequal and communities only get a minor part. Because in the country, since the 2014 fiscal year, mining enterprises of private capital have to pay $7.5 \%$ of their profit to channel the money to the Fondo Regional Sustentable de Estados y Municipios Mineros through payment of three contributions: special right on mining, additional right on mining and extraordinary right on mining.
Económicamente Activa Ocupada (Secretaría del Trabajo y Previsión Social, 2018).

Al revisar el comportamiento del empleo en la industria minero-metalúrgica por subsector, de acuerdo con el Servicio Geológico Mexicano (2018), se observó que de los 371556 empleos del sector minero para el año 2017, la fabricación de productos de minerales no metálicos se ubicó en primer lugar porque registró 142710 empleos, equivalente al $38.45 \%$; las industrias metálicas básicas en segundo lugar con 112751 empleos, equivalente al $30.3 \%$; en tercer lugar la extracción y beneficio de minerales metálicos con 75379 empleos, equivalente al $20.3 \%$; en cuarto lugar la extracción y beneficio de carbón mineral, grafito y otros minerales no metálicos con 38564 empleos, equivalente al $10.4 \%$ y en quinto lugar la explotación de sal con 2152 empleos, equivalente al $0.6 \%$.

Los datos anteriores indicaron que la extracción y beneficio de minerales metálicos contribuyó solamente con la quinta parte del total de los empleos del sector minero del país.

4) Articulación de red de capitales transnacionales. La Bolsa Mexicana de Valores, las casas de bolsa, los bancos, la cadena de proveeduría de maquinaria y servicios tecnológicos y los corporativos mineros, participan como parte de los beneficiarios del valor de la producción minero-metalúrgica de minerales metálicos, que tan solo en el ejercicio fiscal 2017 ascendió a 305.4 mil millones de pesos y de minerales no metálicos a 269.6 mil millones de pesos, cuyo total correspondió a la suma de 575 mil millones de pesos, equivalente a USD\$30 025.3 millones de dólares (Servicio Geológico Mexicano, 2018).

5) Inversión de capital privado. De acuerdo con la Secretaría de Economía (2015 y 2018) la cifra anterior es superior a los USD\$27381.7 millones de dólares de inversión extranjera directa destinada a la minería, equivalente al $3.1 \%$ de los USD $\$ 583$ 522.4 millones de dólares de inversión extranjera directa total captada en México durante los últimos 36 años que abarcan el periodo 1982-2018. Lo que indica el alto nivel de rentabilidad de la industria minera en México, al grado que, en tan solo un año, el valor de la producción obtenido fue superior al total de inversión extranjera recibida para la megaminería durante 36 años. 
The Federal Government perceived an income of 2090.71 million pesos from the aforementioned fund during the 2014 fiscal year, distributed in 25 states of the republic where metallic minerals extraction and refinement take place. From this amount, $70 \%$ was channeled to the states of Coahuila, Chihuahua, Sonora and Zacatecas; plus 2191.74 million pesos of the 2015 fiscal year and 2509.89 million pesos from the 2016 fiscal year giving a total of 6792.35 million pesos during 2014-2016 (Sedatu, 2015a, 2015b, 2016).

This amount contrasts with the production value generated in the 2014 fiscal year in Mexican metallic mining for an amount of USD $\$ 14765^{\prime}$ 299201.46 dollars, resources, mostly transferred to economies such as Canada, The United States and England.

In the 2014 fiscal year, the resources channeled through the Fondo para el Desarrollo Regional Sustentable de Estados y Municipios Mineros were equivalent to only $1 \%$ of the total resources of the mining production value in 2014.

7) Total income perceived for the Federal Government by mining. However, if these numbers are analyzed framed in total income perceived by the federal government according to Fundar (2017), metallic and nonmetallic mining during the 2016 fiscal year only contributed $0.32 \%$ of the total perceived income, including tax collection for concepts of mining rights payment and taxes: income tax (ISR), value-added tax (IVA) and Special Tax on Production and Services (IEPS).

\section{Mapping relations between mega-mining and the impact on human rights}

Human rights have had an incipient treatment by mining corporations in general, although it should also be mentioned that their intervention has been differentiated in each transnational enterprise of private capital.

According to CAMIMEX (2018) a total of 32 mining groups received the Corporate Socially Responsible award given by the Centro Mexicano para la Filantropía during 2018, standing out Peñoles Industries who has received it for 17 straight years, as well as Agnico Eagle
Al hacer un comparativo de origen de inversión de capital privado en la megaminería es la inversión nacional directa la que ha jugado un papel más dinámico, porque para el periodo 2002-2017 tuvo un monto USD\$53 209 millones de dólares, alcanzando un promedio por año de USD\$3 mil 325.5 millones de dólares, prácticamente más del doble de los USD\$24 561 millones de dólares de inversión extranjera directa captados para el mismo periodo, que en promedio por año equivalieron a USD\$1535 millones de dólares.

6) Reparto de la renta minera. Sin embargo, de esa cantidad de recursos privados que se han invertido, al momento de recuperar el capital y obtener ganancias, la distribución de la renta minera es desigual y a las comunidades únicamente les toca una parte marginal. Lo anterior, debido a que en el país desde el ejercicio fiscal 2014 las empresas mineras de capital privado deben pagar el $7.5 \%$ de sus utilidades para canalizarlo al Fondo Regional Sustentable de Estados y Municipios Mineros, mediante el pago de tres contribuciones: derecho especial sobre minería, derecho adicional sobre minería y derecho extraordinario sobre minería.

Durante el ejercicio fiscal 2014 el Gobierno Federal captó ingresos por un monto de 2090.71 millones de pesos del fondo antes mencionado, distribuidos en 25 estados de la república donde está presente la extracción y beneficio de minerales metálicos. De dicho monto, $70 \%$ fue canalizado a los estados de Coahuila, Chihuahua, Sonora y Zacatecas; más 2191.74 millones de pesos del ejercicio fiscal 2015 y, 2509.89 millones de pesos del ejercicio fiscal 2016, dando un total de 6 792.35 millones de pesos durante el periodo 20142016 (Sedatu, 2015a, 2015b, 2016).

Dicho monto contrasta con el valor de la producción generado en el ejercicio fiscal 2014 en la minería metálica mexicana por un monto de USD\$14 765' 299201.46 dólares, recursos, en su mayoría, transferidos a economías como Canadá, Estados Unidos e Inglaterra.

En el ejercicio 2014, los recursos canalizados a través del Fondo para el Desarrollo Regional Sustentable de Estados y Municipios Mineros 
Mexico, Goldcorp and Mexichem who have received it for 11 years for their donations to attend social, economic and cultural rights.

In addition to the above mentioned there is the ISO 14001 environmental management system certification given by international organisms, plus the clean corporate and environmental excellence award given by the Procuraduría Federal de Protección al Ambiente and SEMARNAT to the main mining corporations.

Some community development practices are given as examples, through this practices, mining enterprises perform mitigation actions in human rights: the 213 scholarships given since 2009 by Alamos Gold in Sonora; Plaza El Vergel in Mazapil, Zacatecas by Goldcorp with an investment of six million pesos, summer camps by Minera Autlán in Hidalgo in benefit of 2398 children and young people. Also, Casa Grande Nacozari by Grupo México in Sonora, the Centro de Capacitación by Minera Frisco in communities of Aguascalientes, Baja California, Chiapas, Chihuahua, Sonora and Zacatecas, as well as Peñoles, Proempleo in support of 104 microbusinesses, 282 jobs and 1801 trained people (Camimex, s/f).

Once the aforementioned information has been accepted, it is said that conflicts derived from territorial dispossession associated to mega-mining in Mexico are stared by four main actors: State institutions, private enterprises, civil organizations and affected communities

State institutions, through reforming Article 27 of the Constitution and the enactment of the Mining Law in 1992, facilitate entrance of transnational private capital toward mineral exploitation and refinement. In addition to providing information and public security forces to protect the interests of private mining corporations.

Transnational mining enterprises that produce minerals and have the support of finance capital listed in the world's stock market, mainly from Toronto in Canada, as well as those who supply infrastructure, machinery and maintenance specialized technological services.

Civil organizations protecting the environment such as: Collective, Fronteras Comunes, Greenpeace fueron equivalentes solamente al $1 \%$ del total de recursos del valor de la producción minera en 2014.

\section{7) Captación de ingresos totales para el Gobierno}

Federal por la minería. Sin embargo, si se analizan dichas cifras enmarcadas en la captación de ingresos totales por parte del gobierno Federal, de acuerdo con Fundar (2017), la minería de metálicos y no metálicos durante el ejercicio fiscal 2016, únicamente contribuyó con $0.32 \%$ de los ingresos totales captados, incluida la recaudación fiscal por conceptos de pago de derechos mineros e impuestos: Impuesto sobre la Renta (ISR), Impuesto al Valor Agregado (IVA) e Impuesto Especial sobre Producción y Servicios (IEPS).

\section{Mapeo de relaciones entre megaminería y las afectaciones a los derechos humanos}

Los derechos humanos han tenido un tratamiento incipiente por parte de los corporativos mineros en general, aunque también cabe destacar que su intervención ha sido diferenciada en cada empresa de capital privado transnacional.

De acuerdo con la CAMIMEX (2018), un total de 32 grupos mineros recibieron el distintivo de Empresas Socialmente Responsables por el Centro Mexicano para la Filantropía durante 2018, destacando la industria Peñoles que lo ha recibido por 17 años consecutivos, así como Agnico Eagle México, Goldcorp y Mexichem que lo han obtenido durante 11 años por los donativos para atender derechos sociales, económicos y culturales.

Lo anterior, aunado a las certificaciones de la norma ISO 14001 de sistemas de gestión ambiental otorgadas por organismos internacionales, más los distintivos de industria limpia y excelencia ambiental que han otorgado la Procuraduría Federal de Protección al Ambiente y la SEMARNAT a los principales corporativos mineros.

Como ejemplos se presentan algunas prácticas de desarrollo comunitario, mediante las cuales las empresas mineras realizan acciones de mitigación en derechos humanos: las 213 becas otorgadas desde 2009 por Álamos Gold en Sonora; la Plaza El Vergel en Mazapil, Zacatecas por Goldcorp, con una inversión de seis millones de pesos, campamentos de verano por Minera Autlán en Hidalgo, en beneficio de 2398 
Mexico and REMA, together, carry out resistance actions in defense of the territory by publishing information on web pages, brochures, forums, as well as marches and sit-ins to show the effects of the mining industry in the locations it operates.

Lastly, native peoples affected, mainly, indigenous and peasants who are deprived from their livelihood, especially when they are victims of forced displacement to give way to a new mining project, being left without the houses they used to inhabit or their crop fields.

The international organization Environmental Justice Organizations, Liabilities and Trade EJOLT (2018) had 2637 socioenvironmental conflicts registered at an international level. From this number, Bartra (2014) mentioned that "about $40 \%$ of these involve indigenous populations and between 15 and $20 \%$ have been successful at stopping the aggressive projects", 86 of them correspond to Mexico and 26 to mega-mining in this country, ranking eleventh at a global level because of the great amount of registered conflicts.

Another information source about socioenvironmental conflicts related with megamining, is the organization Observatorio de Conflictos Mineros de América Latina (OCMAL) (2018), in Latin America, mapping of socioenvironmental conflicts sums up to a total of 259 , associated to 220 megamining projects affecting the everyday life of 315 communities, 45 of them located in Mexican territory.

Enciso (2016) mentioned: "there are at least 420 socioenvironmental conflicts in the country, most of them related with mega-mining, energy and water which attempt against ecological balance and the social fabric [...] from which 120 correspond to mining, 80 are part of the energy sector and 75 are related to the water sector".

According to Flores (2017) the research "Impact of metallic mega-mining on water resources" -by the researcher from the Centro de Investigaciones en Geografía Ambiental of the Universidad Nacional Autónoma de México, Sol Pérez- shows that there are 103 current conflicts throughout the country.

According to Ramírez (2017a), the above mentioned happens when transnational enterprises give as mining lease $1.3 \%$ of the production value, because according to data from Informe de la niños y jóvenes. Asimismo, la Casa Grande Nacozari por Grupo México en Sonora, el Centro de Capacitación por Minera Frisco en comunidades de Aguascalientes, Baja California, Chiapas, Chihuahua, Sonora y Zacatecas, así como Peñoles, Proempleo en apoyo a 104 microempresas, 282 empleos y 1801 capacitados (Camimex, s/f).

Aceptado lo anterior, se menciona que los conflictos derivados del despojo territorial asociado a la megaminería en México son protagonizados por cuatro actores principales: instituciones del Estado, empresas privadas, organizaciones civiles y comunidades afectadas.

Las instituciones del Estado, mediante las reformas al Artículo 27 Constitucional y promulgación de la Ley Minera en 1992, facilitan la entrada del capital privado transnacional a la explotación y beneficio de minerales. Aunado a brindar información y los cuerpos de seguridad pública para proteger los intereses corporativos privados mineros.

Las empresas mineras transnacionales dedicadas a la producción de minerales que cuentan con el respaldo del capital financiero que cotiza en las bolsas de valores del mundo, principalmente de Toronto en Canadá, así como de proveedores que les brindan servicios tecnológicos especializados de infraestructura, maquinaria y mantenimiento.

Las organizaciones civiles protectoras del medio ambiente como: Colectivas, Fronteras Comunes, Greenpeace México y REMA, de manera conjunta realizan acciones de resistencia en defensa del territorio, mediante publicación de información en páginas web, folletos, foros, así como marchas y plantones, para darle visibilidad a las afectaciones que produce la industria minera donde opera.

$Y$, por último, los pueblos originarios afectados principalmente indígenas y campesinos, que son despojados de sus medios de vida, sobre todo, cuando son víctimas de desplazamiento forzado para dar paso a un nuevo proyecto minero, quedándose sin sus viviendas que habitaban o sus tierras de cultivo.

La organización internacional Environmental Justice Organisations, Liabilities and Trade EJOLT (2018) tenía registrados 2637 conflictos socioambientales a nivel internacional. De dicha cifra, Bartra (2014), mencionó que "alrededor del 
Auditoría Superior de la Federación, during the 2015 fiscal year, a total number of 59 private enterprises of private capital (Grupo México, Peñoles, Frisco and others from Canada, China, United States and the European Union, among which 12 from Canada stand out) were recognized for tax evasion.

The aforementioned happened because during the fiscal years from 2006 to 2015 only 22397 million pesos on royalties were paid, equivalent to $1.3 \%$ of the total mineral exploitation value for the aforementioned period which was of $1^{\prime} 714342.7$ million pesos.

Paradoxically, the Canadian government pressures Mexican tax authorities so 360 million dollars are reimbursed to Canadian enterprises (Ramírez, 2017b).

It is necessary to elaborate a map of categories corresponding to four generations of human rights, which could show how mining megaprojects do not attend in a wholesome manner international dispositions regarding human rights.

This was documented with empiric information regarding some of the main cases considered as successful with regard to environmental justice in Mexico, either for stopping mining megaprojects, starting legal battles against mining enterprises with favorable ruling for communities or gave rise to the declaration of mining free territories, as it chronologically happened according to Boni (2014), Salazar and Rodríguez (2015), Defiende la Sierra (2016) and UNAM (2017).

In September 2010, representatives of the indigenous community Huichol underwrote an announcement in defense of Wirikuta against a mining enterprise in Catorce, San Luis Potosi.

In April, 2011, through a declaration of the Asamblea de Comunieros, Calpulálpam, Oaxaca was established as the first mining free territory in Mexico. The same thing happened in June 2014 in the indigenous town of Zacualpan, municipality of Comala, Colima. This case was emblematic because it was the first time the agrarian court issued a favorable sentence to build a mining free territory in Mexico.

The Consejo Indígena por la Defensa del Territorio de Zacualpan managed to remove the President of Bienes Comunales who was in favor of installing a mining megaproject from the enterprise Gabfer.
$40 \%$ de estos, involucran poblaciones indígenas y entre el 15 y el $20 \%$ han tenido éxito en interrumpir los proyectos agresivos", 86 de ellos corresponden a México y 26 a la megaminería de este país, ubicándose en el lugar número 11 a nivel mundial por la mayor cantidad de conflictos registrados.

Otra de las fuentes informativas sobre los conflictos socioambientales relacionados con la megaminería es la organización Observatorio de Conflictos Mineros de América Latina (OCMAL) (2018), en Latinoamérica, la cartografía de conflictos socioambientales suma un total de 259 , asociados a 220 megaproyectos mineros, cuya afectación perjudica la vida cotidiana de 315 comunidades, 45 de ellos ubicados en suelo mexicano.

Enciso (2016) señaló: “En el país hay al menos 420 conflictos socioambientales, la mayoría relacionados con minería, energía y agua, que atentan contra el equilibrio ecológico y el tejido social [...] de los cuales, 120 corresponden a minería, 80 son del sector energético y 75 relacionados con el agua".

De acuerdo con Flores (2017), en la investigación titulada: Impacto de la minería metálica en el recurso hídrico - de la investigadora del Centro de Investigaciones en Geografía Ambiental, de la Universidad Nacional Autónoma de México, Sol Pérez-, se advierte que son 103 conflictos vigentes a lo largo del país.

Lo anterior, según Ramírez (2017a) sucede a cambio de que las empresas transnacionales entregan como renta minera el $1.3 \%$ del valor de la producción, porque de acuerdo con datos del Informe de la Auditoría Superior de la Federación, durante el ejercicio fiscal 2015 un total de 59 empresas privadas de capital transnacional (Grupo México, Peñoles, Frisco y otras de Canadá, China, Estados Unidos y Unión Europea, entre las que sobresalen 12 de origen canadiense) fueron detectadas en situación de evasión de impuestos.

Lo anterior, porque durante los ejercicios fiscales correspondientes a los años 2006 al 2015 únicamente pagaron derechos por 22397 millones de pesos, equivalente al $1.3 \%$ del valor total de la explotación de minerales para el periodo antes mencionado que ascendieron a 1'714 342.7 millones de pesos.

Paradójicamente el gobierno canadiense ejerce presión a las instancias fiscales mexicanas para 
After the previous three cases, there were new collective actions in defense of the territories against mining megaprojects, to the degree of currently having two thousand communities declared as mining free communities in the Mexican territory.

Some of the most representative cases happened during 2012: the formation of the Asamblea Veracruzana de Iniciativas y Defensa Ambiental (LAVIDA) against the mining megaproject of Caballo Blanco in Veracruz; in June, 2014 in Cerro San Pedro, San Luis Potosi; in September, in el Itsmo de Tehuantepec, Oaxaca and in Baja California Sur; November in the ejido Las Canoas, Colima. In January, 2015 in Ixtacamaxtitlán, Puebla; February in Xochitepec and Temixco Morelos; in March and August in Chiapas in the municipalities of Acacoyagua, Cintalapa, Escuintla, Huehuetán, Mazatán, Tapachula, Tonalá, Tuxtla, Suchiapa and Soconusco respectively; November, in the municipalities of Ejutla de Crespo, Ocotlán de Morelos and Tlacolula de Matamoros, Oaxaca and lastly, in April 2016, in Ixtepec, Oaxaca.

\section{First Generation. Civil rights}

In regard to civil rights, the mining industry could represent a risk by setting aside equality in dignity, liberty, security and life; also when different ways of discrimination and torture are practiced to those opposing extractive megaprojects, this could vanish acknowledgement of the legal figure and the right to start a family.

The previous situation took place in the state of Chiapas according to OCMAL (2015), as expressed by Jesús Alfonso Ochoa, supporter of mining free communities, in his testimony:" there is also violence, harassment, homicides, dispossession and eviction of the communities or supporters who have decided to fight for our lands, we do not intend to take anything from anyone, we only demand what is ours".

In addition, it was mentioned in Defiende Sierra (2016) that this problem also happened at Itsmo de Tehuantepec, Oaxaca, through the Zanatepec Declaration in the fight for the right to life.

At the M4 movement (2016) the testimony of Esperanza Salazar was registered, Coordinator of Colectivo Bios Iguana, Colima, who among other activities, articulated actions of resistance along with que le sean reintegrados 360 millones de dólares a empresas canadienses (Ramírez, 2017b).

Resulta necesario realizar un mapeo expresado en categorías correspondientes a cuatro generaciones de derechos humanos, que contemple la manera en que los megaproyectos mineros no atienden de manera integral las disposiciones internacionales en materia de derechos humanos.

La cual se documentó con información empírica sobre algunos de los principales casos considerados exitosos en materia de justicia ambiental en México, ya sea porque permitieron detener megaproyectos mineros, emprendieron batallas legales contra las empresas mineras con sentencia favorable para las comunidades o dieron lugar a la declaratoria de territorios libres de minería, como ocurrió cronológicamente, de acuerdo con Boni (2014), Salazary Rodríguez (2015), Defiende la Sierra (2016) y UNAM (2017).

En septiembre de 2010, los representantes de la comunidad indígena huichol suscribieron un pronunciamiento en defensa de Wirikuta contra una empresa minera en Catorce, San Luis Potosí.

En abril de 2011, mediante una declaratoria de la Asamblea de Comuneros, Calpulálpam, Oaxaca, se estableció en México como el primer territorio libre de minería. Lo mismo sucedió en junio 2014, en la localidad indígena de Zacualpan, municipio de Comala, Colima. Este caso es emblemático, porque fue la primera ocasión que un tribunal agrario dictó una sentencia favorable para constituir un territorio libre de minería en México.

El Consejo Indígena por la Defensa del Territorio de Zacualpan logró destituir al Presidente de Bienes Comunales que estaba a favor de que se instalara un megaproyecto minero de la empresa Gabfer.

Posterior a estos tres casos, surgieron nuevas acciones colectivas de defensa del territorio ante megaproyectos mineros, al grado de que actualmente ya se cuenta con dos mil comunidades declaradas libres de minería en el territorio mexicano.

Algunos de los casos más representativos ocurrieron en 2012: la conformación de la Asamblea Veracruzana de Iniciativas y Defensa Ambiental (LAVIDA), contra el megaproyecto minero de Caballo Blanco en Veracruz; en junio de 2014 en Cerro San Pedro, San Luis Potosí; en septiembre, en el Istmo de Tehuantepec, Oaxaca y en Baja California Sur; noviembre, en el ejido Benito 
the Consejo Indígena por la Defensa del Territorio de Zacualpan, Comala, Colima, which highlighted:

"...the Consejo Indígena and Bios Iguana have received many threats, they have been death threats mainly made by the ex-president of Bienes Comunales. [...] the son of the delegate of the Procuraduría Agraria also threatened to kill a member of Bios Iguana, members from the Consejo Indígena were threatened by the mining businessman who wants to install a mine in Zacualpan. [...] In 2014 a tankette was bought for the State. [...] that tankette has been used in three occasions and the three occasions have been to suppress the indigenous community of Zacualpan..."

In SubVersiones (2016) a testimony of a peasant defending the Archeological site of Xochicalco in the municipality of Temixco, Mor., was published, who stated:

"...Adults have been dying, those people had the courage to defended the town, elder people did take into consideration costums and traditions, because the town is allegedly governed by customs and traditions, but the offspring of those people have deviated a lot, there is no dignity, there is no pride to love what is really worth it, all of them have a materialistic mind".

\section{Second Generation. Political rights.}

Mining at a large scale can put at risk political rights in the Mexican territory when the right to be publicly heard and to an effective resource before national courts is affected, when leaders opposing mining megaprojects are arbitrarily arrested.

Political rights can also be affected by interfering in the private life and in the houses of the members of peasant and indigenous communities, or when their right to freely circulate, to choose residence and even their own nationality is broken. The same thing happens when the freedom of thought, conscience, religion, opinion, expression, reunion and association are attempted on, as well as to restrict the right to free elections and to participate in government.

At M4 Movement (2014), the testimony of Esperanza Salazar, Coordinator of Bios Iguana, Colima was acknowledged, regarding the resistance against the imposition of the surface mining megaproject
Juárez, Chihuahua y en Cuetzalan de Progreso, Puebla; diciembre, en el ejido Las Canoas, Colima. En enero de 2015 en Ixtacamaxtitlán, Puebla; febrero en Xochitepec y Temixco Morelos; marzo y agosto en Chiapas en los municipios de Acacoyagua, Cintalapa, Escuintla, Huehuetán, Mazatán, Tapachula, Tonalá, Tuxtla, Suchiapa y Soconusco, respectivamente; noviembre, en los municipios de Ejutla de Crespo, Ocotlán de Morelos y Tlacolula de Matamoros, Oaxaca, y, por último, en abril de 2016 en Ixtepec, Oaxaca.

\section{Primera generación. Derechos civiles}

En cuanto a los derechos civiles, la industria minera podría representar un riesgo al dejar de lado la igualdad en dignidad, la libertad, la seguridad y la vida; también cuando se practiquen distintas formas de discriminación y tortura a los opositores a los megaproyectos extractivos, lo mismo podría desvanecer el reconocimiento de la personalidad jurídica y el derecho a fundar una familia.

La situación anterior se presentó en el estado de Chiapas, de acuerdo con OCMAL (2015) tal como expresó su testimonio Jesús Alfonso Ochoa, defensor de comunidades libres de minería, señaló: "también está la violencia, hostigamiento, homicidios, despojos y desalojos de las comunidades o defensores que hemos decidido luchar por nuestras tierras, no pretendernos quitarle nada a nadie, exigimos solamente lo que nos pertenece".

Asimismo, en Defiende la Sierra (2016) se mencionó que dicha problemática también ocurrió en el Istmo de Tehuantepec, Oaxaca, a través de la Declaratoria Zanatepec en la lucha por la defensa del derecho a la vida.

En Movimiento M4 (2016) se recabó el testimonio de Esperanza Salazar, Coordinadora del Colectivo Bios Iguana, Colima, quienes entre otras actividades, articularon acciones de resistencia conjuntamente con el Consejo Indígena por la Defensa del Territorio de Zacualpan, Comala, Colima, en el que destacó:

“...tanto el Consejo Indígena como Bios Iguana han recibido muchas amenazas, han sido amenazas de muerte, principalmente por el expresidente de Bienes Comunales. [...] el hijo de la delegada de la Procuraduría Agraria también amenazó de muerte a un compañero de Bios Iguana, compañeros del Consejo Indígena fueron amenazados por el propio 
of the enterprise Gabfer to extract gold: "a mine of that nature can cause the displacement of the communities as we have seen in other places".

Salazar and Rodríguez (2015) highlighted that one of the most distinctive traits of the collective acts of resistance against mega-mining in Calpulalpám, Oax., has been the customs and traditions system in which the collective well-being is established as a priority through a project of local development with medium and long-term perspective. The testimony of the president of Comisariado de Bienes Comunales mentioned:

"It is very complicated to say to someone "here is the money", not even to the Municipal President because there is the Council and then there is the Assembly, people are very strict here. (...) It is taken with respect what the Assembly says, that is what has been difficult for the enterprises, they have not been able to corrupt our people. That is the strength of Calpulalpám, the organization of its community is very strong."

\section{3) Third generation. Social, economic and cultural rights.}

From the dynamic in which extractive capital operates, at the same time profit and the mining lease are being transferred, the right to property would also be violated when the means of production and social reproduction (lands, houses and public spaces) of peasant and indigenous communities are destroyed.

The same thing happens when the right to work is affected because the traditional forms of local subsistence economy are destroyed; as well as the right to housing, education, culture, physical culture, sports and rest, all would be affected by mining enterprises.

Third generation rights are also violated when human rights to health, food and medical assistance are affected; when water resources for human consumption, agricultural and livestock use become dried or polluted or when air and soil become polluted causing an increase in respiratory and chronic degenerative diseases.

The Movimiento Morelense against Minería de Metales Preciosos set a stance of rejection against empresario minero que quiere instalar la mina en Zacualpan. [...] En 2014 se compró una tanqueta para el estado. [...] esa tanqueta se ha utilizado solamente en tres ocasiones y las tres ocasiones han sido para reprimir a la comunidad indígena de Zacualpan..."

En SubVersiones (2016), se presentó el testimonio anónimo de campesino en defensa del sitio Arqueológico de Xochicalco, en el municipio de Temixco, Mor., quien señaló:

"...A la gente adulta pues ya se han ido muriendo, esa gente tenía mucho coraje para defender el pueblo, la gente mayor si hacían valer lo que le llaman usos y costumbres, porque el pueblo se rige supuestamente por usos y costumbres, pero ya los hijos que han ido quedando de esas personas ya se desviaron mucho, ya no hay dignidad, no hay orgullo para amar lo que verdaderamente vale la pena, todos han materializado su mente".

2) Segunda generación. Derechos políticos.

La minería a gran escala podría poner en jaque los derechos políticos en el territorio mexicano, cuando se afecte el derecho a ser oído públicamente y a un recurso efectivo ante los tribunales nacionales, cuando se detiene de manera arbitraria a los líderes que se oponen a los megaproyectos mineros.

También se afectarían los derechos políticos mediante la injerencia en la vida privada y el domicilio de los integrantes de comunidades campesinas e indígenas, o cuando se les quebranta el derecho a circular libremente, a elegir su residencia, hasta su propia nacionalidad. Lo mismo ocurre cuando se atenta contra la libertad de pensamiento, conciencia, religión, opinión, expresión, reunión y asociación, así como al coartar el derecho a votar libremente y a participar en el gobierno.

En Movimiento M4 (2016), se conoció el testimonio de Esperanza Salazar, Coordinadora del colectivo Bios Iguana, Colima, sobre la resistencia ante la imposición de un megaproyecto minero a cielo abierto de la empresa Gabfer para extraer oro: "el riesgo que puede acarrear una mina de esa naturaleza también representa el desplazamiento de las propias comunidades como lo hemos visto en otros lugares." 
the mining megaproject Esperanza Silver, mainly of Canadian capital, which wants to be allocated in the municipality of Temixco, Mor., because according to Tamayo (2014), it would affect the biodiversity of 15000 hectares and the Archeological Site of Xochicalco, which was declared as a World Heritage Site by the United Nations, Educational, Scientific and Cultural Organizations (UNESCO) in 1999. Additionally, the movement argued that:

1. It will affect and pollute the water resources of Cuernavaca and other municipalities in Morelos.

[...] 2. It will affect the health of the inhabitants and the ecosystems of all the region. [...] 3. It will harm the social fabric. [...] 4. It is an act of Colonialism. [...] It not only affects ecosystems and aquifers, but also the inhabitants and their lots. Open surface mining is not compatible with other land uses (such as agriculture, housing or recreation). 5. It will affect the Archeological Site of Xochicalco. [...] 6. The mine Esperanza Silver, at the end of its operation (a little bit after a decade) will only leave the worst poverty and destruction in the region.

SubVersiones (2016) gathered a pair of anonymous testimonies in defense of the territory of Xochicalco, one from a female peasant mentioned:

"When they destroy the hill, palm trees will be practically depleted. [...] many people come for wood, we call it venir por leña because it means gathering dry wood, cut dry and it is part of the livelihood of the town, we make tortillas over there, we cook tortillas, the coal is made from the wood."

Another testimony was made by a peasant who mentioned: "a form of survival is looked for and here the hill has many things, palm trees. My grandfather weaved chairs, repaired chairs and he used the hill because he used to come and cut palm leaves to weave chairs".

Due to lobbying of the government of the state of Morelos and the citizenship's resistance, in June 2013, Semarnat denied authorization for mining exploration to the mining enterprise Esperanza Silver.

Regarding impacts on health caused by mining enterprises, in Medio Ambiente and Sociedad (2012), the testimony of Mario Martínez, member of the Red Mexicana de Afectados por la Mineria and the Frente Amplio Opositor a Mineria San Javier, as well as two anonymous testimonies from women.
En Salazar y Rodríguez (2015), se destacó que uno de los rasgos distintivos de las acciones colectivas de resistencia ante la megaminería en Calpulálpam, Oax., ha sido el sistema de usos y costumbres, mediante el cual se establece como prioridad el bienestar colectivo, a través de un proyecto de desarrollo local con perspectiva de mediano y largo plazo. El testimonio del presidente del Comisariado de Bienes Comunales señaló:

"Aquí está muy complicado que a alguien le diga ahí está la lana, ni al Presidente Municipal porque está el Consejo y luego está la Asamblea, aquí es muy estricta la gente. (...) Se respeta lo que dice la Asamblea, eso es lo que ha sido muy difícil para las empresas, que no han podido corrompernos.

Esa es la fortaleza de Calpulálpam la organización comunitaria es muy fuerte."

\section{3) Tercera generación. Derechos sociales,} económicos y culturales

A partir de la dinámica en la que operan los capitales extractivos, a la par que se transfiere la ganancia y la renta minera, también se vulneraría el derecho a la propiedad cuando se destruyen los medios de producción y reproducción social (tierras, viviendas y espacios públicos) de las comunidades campesinas e indígenas.

Lo mismo ocurre con la afectación al derecho al trabajo cuando se destruyen las formas tradicionales de economía local de subsistencia; al igual que el derecho a la vivienda, a la educación, a la cultura, a la cultura física, al deporte y al descanso, todos se verían afectados por las empresas mineras.

También se vulnerarían los derechos de tercera generación cuando se afecte el derecho humano a la salud, alimentación y asistencia médica; cuando se agoten y contaminen las fuentes de agua para consumo humano, para uso agrícola y pecuario, o cuando se contamine el suelo y el aire, lo que provoque el incremento de enfermedades respiratorias y crónico-degenerativas.

El colectivo denominado Movimiento Morelense contra la Minería de Metales Preciosos, fijó su postura de rechazo al megaproyecto minero de Esperanza Silver, de capital canadiense principalmente, que pretende ubicarse en el municipio de Temixco, Mor., porque de acuerdo con Tamayo (2014), indicó que 
Mario Martínez mentioned: "people are dying from diseases, the most characteristic cancer is in kidneys, there are a lot of people getting dialysis." Additionally, an anonymous female adult mentioned:

"Intoxications damaging the internal physiological organism when they start to absorb dust or when cyanide infiltrates, for instance, in places where there is water in this area, damage in the form of malformations in creatures (babies) that are born, people who get pregnant lose, their products (babies) are lost."

Another anonymous female adult mentions:

"Down here in Rancho La Zapatilla, they do not want to show the effect its having. One admitted one of my daughters for two months. [...] when I got her out off the 50 she was swollen for about a month, the swollenness decreased, she was admitted and several studies were made, but then she started to get marks, like skin burns. [...] But then, can you believe it, with all the dust that gets there, the water, it all gets polluted."

Another case was originated due to the mining concession given by the Mexican Government to the Canadian transnational First Majestic Silver Corporation in Wirikuta, San Luis Potosi, considered as a sacred place inhabited by the Huichol indigenous community. Public, free, previous and informed consultation was violated because the Huichol community was never taken into consideration regarding this mining venture.

Human rights to property, religion, culture and responsibilities regarding the Wixarikas indigenous community were also violated. According to the 169 Agreement of the International Labor Organization, the Universal Declaration of Human Rights, The United Nations Declaration on Indigenous Peoples in 2007, which were ratified in 2014 in the framework of the First World Conference on Indigenous Peoples at the UN.

Therefore, in September 2010, Boni (2014) mentioned:

"Representatives from the Huichol indigenous group met in Mezquitic, Jalisco, to sign a document titled "Pronunciamiento en defensa de Wirikuta". This document manifests the rejection to open a mine in Sierra de Catorce at the north part of the state of San Luis Potosi, by a Canadian mining company. The main demand was: afectaría la biodiversidad en una superficie de 15 000 hectáreas y el Sitio Arqueológico de Xochicalco, mismo que fue declarado por la Organización de las Naciones Unidas para la Educación, la Ciencia y la Cultura (UNESCO) en el año de 1999, como patrimonio cultural de la humanidad. Asimismo, dicho movimiento argumentó que:

1. Afectará y contaminará los recursos hídricos de Cuernavaca y otros municipios morelenses. [...] 2. Afectará la salud de los habitantes y los ecosistemas de toda la región. [...] 3. Dañará el tejido social. [...] 4. Constituye un acto de colonialismo. [...] afecta no solo a ecosistemas y acuíferos sino a los pobladores y sus parcelas. La minería a tajo abierto no es compatible con otros usos del suelo (como la agricultura, la habitación o la recreación). 5. Afectará el Sitio Arqueológico de Xochicalco. [... 6. 6. La minera Esperanza Silver, al término de su operación (después de poco más de una década) solo dejará la peor pobreza y destrucción en la región.

En SubVersiones (2016), se recabaron un par de testimonios anónimos en defensa del territorio de Xochicalco, el de una campesina destacó:

"Ahora que destruyan el cerro pues prácticamente se va a acabar la palma. [...] mucha gente se viene acá a la leña, le llamamos venir a la leña porque es juntar la leña seca, cortar seco, y es de lo que en el pueblo se vive, allá pues hacemos la tortilla, se cocinan tortillas, de la leña se saca el carbón."

Otro de los testimonios fue de un campesino que señaló: "Se busca una forma de sobrevivir y aquí el cerro tiene muchas cosas, la palma. Mi abuelo tejió sillas, reconstruía sillas y él usaba el cerro mucho porque él venía a cortar palma para tejer las sillas."

Derivado de las gestiones del gobierno del estado de Morelos y la resistencia ciudadana, durante el mes de junio de 2013, la Semarnat negó a la empresa minera Esperanza Silver la autorización de explotación minera.

Sobre los impactos a la salud por parte de las mineras, en Medio Ambiente y Sociedad (2012), se obtuvo el testimonio de Mario Martínez, integrante de la Red Mexicana de Afectados por la Minería y del Frente Amplio Opositor a la Minera San Xavier, así como dos testimonios anónimos de mujeres. Mario Martínez mencionó: "Ya está muriendo gente a causa de enfermedades, de cánceres lo más característico 
Immediate cancelation of 22 mining concessions owned by the transnational enterprise and the establishment of an indefinite moratorium so new exploitation and exploration permits will not be issued in the desert of Real de Catorce nor in any other sacred place nearby. [...] mining violates the sanctity of this place by drying and polluting natural water sources. [...] it would contribute to aggravate the extermination war against our indigenous peoples."

Subsequently, in Autoridades Tradicionales y Agrarias del Pueblo Wixárika (2017) through an announcement of the Consejo Regional Wixárika por la defensa de Wirikuta held in January 2017 highlighted:

"The undersigned ratify our dignified struggle and legitimate defense in favor of our sacred territories, as well as altars and places found in the confines of our Wixarika world and in the geography we currently live in. We will continue to defend our Botanical Garden and habitat of the Wirikuta, a place where equilibrium is centered and where the essences of life are founded.

Because allowing the destruction and operation by transnational enterprises, mainly mining ones, is the same thing as allowing the extermination and annihilation of a culture that exists since immemorial times, this means that the Wixarika culture, against this situation, will not take a step back until we achieve efficiency, recognition and respect of the Wirikuta ecosystem, and in particular to be declared free of mining and threats from the highest standards [...] to keep our culture alive, but specially so our descendants lives can reign. At a second level we work under the orders of the Assemblies of comuneras and comuneros"

In the state of Chiapas, the municipalities of Tapachula, Huehuétan, Mazatán, Suchiapa, Tuxtla, Acacoyagua, Escuintla, Cintapala and Tonala were declared mining free location because of the different violations to human rights. According to OCMAL (2015), Rosa's testimony was registered regarding the way rights to health, water and food are violated, expressed from her husband's health situation, she mentioned:

"...they said it was something related to the liver, but they did not say more, in the health centers they should at least tell you were the disease is, it is at least es siempre de riñón, hay mucha gente dializándose." Asimismo, una mujer adulta mayor anónima, señaló: "Las intoxicaciones a los daños internos fisiológicos del organismo cuando empiezan a absorber polvos, o cuando llega a filtrarse el cianuro, por ejemplo, en los lugares donde tenemos el agua en esa zona, daños en la cuestión de malformaciones en las criaturas que llegan, las personas que llegan a embarazarse pierden, se pierden los productos." Otra mujer adulta anónima mencionó: "Aquí abajito en el Rancho La Zapatilla, no quieren enseñar el efecto que les está haciendo. Una tuvo como dos meses internada una hija mía. [...] después de que la saqué del 50 duró como un año hinchada, se le calmó aquello hinchado, estuvo internada y le hicieron muchos estudios, pero luego le salieron unas manchas, así como quemadas. [...] Pero pues usted cree, con todo el polvo que se va para allá, el agua, todo eso se contamina.

Otro caso se originó debido a la concesión minera que otorgó el gobierno de México a la transnacional canadiense First Majestic Silver Corporation en Wirikuta, San Luis Potosí, considerado un lugar sagrado habitado por la comunidad indígena huichol. Se vulneró lo referente a la consulta pública, libre, previa e informada, porque la comunidad huichol nunca fue tomada en cuenta sobre este emprendimiento minero.

También se vulneraron los derechos humanos a la propiedad, a la religión, la cultura y deberes respecto a la comunidad de los indígenas wixárikas. De acuerdo con lo que establece el Convenio 169 de la Organización Internacional del Trabajo, la Declaración Universal de Derechos Humanos, la Declaración de la ONU sobre Pueblos Indígenas de 2007, mismos que fueron ratificados en el año 2014, en el marco de la primera Conferencia Mundial de los Pueblos Indígenas en la ONU.

Por ello, en septiembre de 2010, Boni (2014) señaló: "Representantes del pueblo huichol se reunieron en Mezquitic, Jalisco, para firmar un documento titulado "Pronunciamiento en defensa de Wirikuta". En él manifestaban su rechazo a la apertura de una mina en la sierra de Catorce, al norte del estado de San Luis Potosí, por parte de una compañía minera canadiense. La demanda central era esta:

La cancelación inmediata de las 22 concesiones mineras en poder de la transnacionaly que se fije una 
something. We knew he had cancer when he was dead, everything that they explained was related to the mines that surround the region and have us trapped, because we know that in several communities of Chiapas you breathe cancer as if it were air. [...] those enterprises have been the ones that caused our cancer, why not, if we drink polluted water, eat polluted fish, wash our food and grow them with polluted and mortal liquid."

The same thing happened in the municipality of Ixtacamaxtitlán, Pue., where through a lobbying agreement they declared it a "free mining territory", specially against the megaproject Almaden Minerals, because according to Municipios Puebla (2015) they wanted to avoid what happened in cases like El Carrizalillo, Gro., in order to do so, they learned from the research made by Miguel Mijangos from REMA, who declared:

"... children, women and men with their bodies full of scabs and dryness, irritated eyes, newborns with malformations; and testimony of what cannot be seen: the increase of nervous system, digestive, respiratory and lung diseases such as scoliosis and even cancer. In addition to premature births. When the environment is altered, all of us who live in it suffer different alterations. One of the first manifestations were health problems."

Florilia Cruz from Ejido Ovando Turquía in Esquitla, Chiapas, also expressed her preoccupation in regard to fundamental human rights: "our health, so each and everyone of our inhabitants expressed their opinion, reaching the conclusion that no mine will be allowed to open in our ejido." (Defiende la Sierra, 2016).

The same thing happened in Itsmo de Tehuantepec according to Defiende la Sierra (2016) through the Declaratoria de Zanatepec, in defense of the right to land property.

In Movement M4 (2016) the testimony of Esperanza Salazar, Coordinator of the collective Bios Iguana, Colima was offered:

"The harm would be enormous, especially because the mountain would be affected and there are about 100 hectares, as a matter of fact, there are two concessions and the other concession also has 100, we are talking about 200 hectares. They live from agriculture, so the impact a mine of this nature has, also implies displacement of the own communities, as we have seen in other places." moratoria indefinida para que no se expidan nuevos permisos de explotación o exploración en el desierto de Real de Catorce ni en ningún lugar circunvecino a nuestros lugares sagrados. [... l la minería vulneraría la sacralidad de este sitio mediante el desecamiento y contaminación de las fuentes naturales de agua.

[...] contribuiría a agudizar la guerra de exterminio contra nuestros pueblos indígenas. "

Posteriormente en Autoridades Tradicionales y Agrarias del Pueblo Wixárika (2017), mediante un pronunciamiento del Consejo Regional Wixárika por la defensa de Wirikuta realizado en enero de 2017, destacaron:

"Los suscritos ratificamos nuestra lucha digna y defensa legítima a favor de nuestros territorios sagrados, así como sus altares y lugares sagrados que se encuentran en los confines de nuestro mundo Wixárika y en la geografía en la que actualmente vivimos. Con especial énfasis seguiremos defendiendo nuestro Jardín Botánico y hábitat de Wirikuta, espacio en el cual se centran los equilibrios y donde se fundan las esencias de la vida.

Ya que, el permitir la destrucción y operación por parte de las empresas trasnacionales, principalmente mineras, es permitir el exterminio y aniquilamiento de una cultura que existe desde los tiempos inmemoriales, es decir, la cultura Wixárika, ante ello no daremos ni un paso atrás, hasta lograr la efectividad, reconocimiento y respeto del ecosistema de Wirikuta $y$, sobre todo, quede declarado libre de minería y de toda amenaza desde los estándares más altos. [...] para seguir manteniendo viva nuestra cultura y, sobre todo, porque reine la vida de nuestros descendientes. $Y$ en segundo plano, trabajamos bajo las órdenes de las asambleas de comuneros y comuneras."

En el estado de Chiapas, los municipios de Tapachula, Huehuetán, Mazatán, Suchiapa, Tuxtla, Acacoyagua, Escuintla, Cintalapa y Tonalá, fueron declarados libres de minería por las diversas afectaciones a los derechos humanos. De acuerdo con OCMAL (2015), se recabó el testimonio de Rosa sobre la manera en que se transgreden los derechos a la salud, agua y alimentación, expresado a partir de la situación de salud de su marido, ella señaló:

"...dijeron que se trataba de algo en el hígado, pero no nos dijeron más, en los centros de salud que al menos te digan dónde tienes el mal, ya es 
4. Fourth generation. Solidarity or indigenous peoples rights.

Due to the thirst for profits from the transnational and national mining enterprises of private capital, surface mining megaprojects have been imposed in the Mexican territory at the expense of violating the right to social and international order.

The aforementioned happens, controversies and litigations established in international courts such as Centro Internacional de Arreglo de Diferencias Relativas a Inversiones do not matter, violating rights and liberties established in the Universal Declaration of Human Rights, as well as in several protocols and agreements related to human rights; also affecting the right to development, selfdetermination and peace of the indigenous peoples and communities, the right to nature and a healthy environment, water and sanitation, the use of nonpolluting energy as well as transparency and access to information.

At CNN Español (2007) the testimony of Mario Martínez and Juan Carlos Ruíz was obtained, two members of Frente Amplio Opositor a la Minera San Xavier, in San Luis Potosi. Mario Martínez mentioned:

"The courts decided to cancel the permit because they considered it violated the agreement we are talking about, as well as other environmental normativity such as norm 59, articles of the Ley General del Equilibrio Ecológico y Protección al Ambiente. [...] Minera San Xavier got legal protection, it loses that protection, it got dismissed and Semarnat gives them a new permit."

Juan Carlos Ruiz mentioned:

"We are facing a violation of environmental law, we are facing an issue of depredation of the historical and environmental heritage. [...] there are 32 million liters of water mixed daily with 16 tons of cyanide and the daily use of 25 tons of explosives to throw down between 70 thousand and 80 thousand tons of rocks from the hill per day, one kilometer of mountains is going to disappear and at the end of the project, which lasts only nine years, it is a nine year project, which will leave a pit of one and a half kilometers of diameter and 300 meters deep; in addition to the 500 hectares of depredation of areas that include lands of the ejido Cerro de San Pedro. [...] symbol of the state of San Luis Potosi since 1824." ganancia. Supimos que tenía cáncer cuando ya estaba muerto, todo lo que nos explicaron tenía que ver con las mineras que rodean la región y nos tienen atrapados, porque todos sabemos que distintas comunidades de Chiapas el cáncer se respira como el aire. [...] que han sido esas empresas las que han provocado nuestro cáncer, y cómo no, si bebemos agua contaminada, comemos peces contaminados, lavamos nuestros alimentos y los cultivamos con líquido contaminado y mortal."

Lo mismo ocurrió en el municipio de Ixtacamaxtitlán, Pue., donde mediante acuerdo de cabildo declararon "territorio libre de minería", principalmente contra el megaproyecto de Almaden Minerals, porque según Municipios Puebla (2015), pretendían evitar lo que ocurrió en casos como El Carrizalillo, Gro., para ello tomaron conocimiento de la investigación realizada por Miguel Mijangos de la REMA, quien declaró:

"...niños, mujeres y hombres con el cuerpo lleno de costras y resequedad, los ojos irritados, recién nacidos con malformaciones; y el testimonio de lo que no se ve: el crecimiento de las enfermedades nerviosas, las digestivas, las respiratorias $y$ pulmonares como la silicosis y hasta el cáncer. Además de la proliferación de partos prematuros. Cuando el ambiente se altera, todos los que vivimos en él sufrimos alteraciones de distintas maneras. $Y$ una de las primeras manifestaciones fueron los problemas de salud."

Asimismo, Florilia Cruz del Ejido Ovando Turquía, municipio de Esquintla, Chiapas, expresó su preocupación por los derechos humanos fundamentales: "nuestra salud, por lo que todos y cada uno de nuestros habitantes se dio su opinión, llegando a la conclusión de que no se dejará abrir ninguna mina en nuestro ejido." (Defiende la Sierra, 2016).

Así como en el Istmo de Tehuantepec, Oax., de acuerdo con Defiende la Sierra (2016), ocurrió a través de la Declaratoria Zanatepec, en la defensa del derecho a la propiedad de la tierra.

En Movimiento M4 (2016) se ofreció el testimonio de Esperanza Salazar, Coordinadora del colectivo Bios Iguana, Colima:

"El daño que se haría sería bastante grande, sobre todo, porque se va a afectar una montaña, y son más o menos 100 hectáreas, de hecho, son dos 
In Medio Ambiente y Sociedad (2012), the testimony of Mario Martínez was registered, member of the Red Mexicana de Afectados por la Minería y del Frente Amplio Opositor a la Minera San Xavier who mentioned:

"Article 27 of the constitution was changed. [...] that was the entrance to get into the North American Free Trade Agreement. The Free Trade Agreement was signed in 1994 and in 1995 the mining enterprises started to enter. If you pay attention, the Secretary of Economy has gone abroad, he has gone to China to give away the country, to tell the Chinese to invest in Mexico, as you know China is an industrial power and needs a big amount of minerals, well, they go all the way there. Go to Mexico, there we have our country, $70 \%$ of it is mineralized, we will give you all the facilities, enterprises do not pay taxes here in Mexico because they do social work, what they call corporate social responsibility, so instead of paying taxes, they paint the church, pave a small section of the road, they give one or two computers to a school, they organize a festival on mother's day, they give them a little basket, a bag with groceries. Those are our country's policies, the sellout policies of our country are giving away our territory, they are giving away our economy, they are giving away everything in benefit of small groups with enterprise power."

Movement M4 (2016) presented the testimony of Esperanza Salazar, Coordinator of collective Bios Iguana, Colima:

"The indigenous community of Zacualpan [...] has biological richness [...] and it also has one spring, where the community gets its water supply [...] but also to two cities located in Colima and Villa de Álvarez, there are a total of 300000 people. The mine they want to install and exploit [...] is a gold, silver and copper mine, this means that a large amount of chemical substances will be used, such as cyanide and it also means that they are going to extract a large amount of rocks from the subsoil, and this, the contact of the water, the air and these substances release other substances such as heavy metals, this is one of the main sources of pollution."

In regard to the violation of these type of rights, Jesús Alfonso Ochoa, defender of mining free communities in the state of Chiapas according to OCMAL (2015), pointed out that: concesiones y la otra concesión también es de 100, estamos hablando de 200 hectáreas. Ellos viven de la agricultura, entonces el riesgo que puede acarrear una mina de esa naturaleza también representa el desplazamiento de las propias comunidades, como lo hemos visto en otros lugares."

\section{Cuarta generación. Derechos de solidaridado} de los pueblos.

Ante la sed de ganancias por las empresas mineras de capital privado transnacional y también nacional, se han impuesto los megaproyectos mineros a cielo abierto en el territorio mexicano a costa de vulnerar el derecho al orden social e internacional.

Lo anterior ocurre sin importar las controversias y litigios que establezcan ante cortes internacionales como el Centro Internacional de Arreglo de Diferencias Relativas a Inversiones, violentando los derechos y libertades establecidos en la Declaración Universal de Derechos Humanos, así como en diversos protocolos y convenios en materia de derechos; afectando también el derecho al desarrollo, a la autodeterminación y la paz de los pueblos y comunidades indígenas, el derecho a la naturaleza y al medio ambiente sano, al agua y saneamiento, al uso de energía no contaminante, así como de transparencia y acceso a la información.

En CNN en Español (2007), se obtuvo el testimonio de Mario Martínez y Juan Carlos Ruiz, dos integrantes del Frente Amplio Opositor a la Minera San Xavier, en San Luis Potosí. La opinión de Mario Martínez señaló:

"Los tribunales deciden anular el permiso por considerar que este permiso era violatorio, tanto al decreto que estamos hablando como a otras normatividades ambientales como la norma 59, como los artículos de la Ley General del Equilibrio Ecológico y Protección al Ambiente. [...] Minera San Xavier se ampara, pierde los amparos, se los sobreseen y SEMARNAT le da un permiso nuevo."

Juan Carlos Ruiz mencionó:

"Estamos ante un problema de violación de las leyes ambientales, estamos ante un problema de depredación del patrimonio histórico y ambiental. [...] son 32 millones de litros de agua diarios mezclados con 16 toneladas de cianuro y el uso de 25 toneladas de explosivos diarios para tumbar entre 
"The problem is worse when not only the Federal and the State Government grant direct access to the mining enterprises so they can destroy what is left of Chiapas, but they also allow 'almost in an illegal manner, the extraction of titanium in mines located in regions of high diversity, forests and water springs in the Natural Protected Areas of Chiapas."

As it was mentioned by Florilia Cruz from Ejido Ovando Turquía, municipality of Esquintla, Chiapas in 2015, who spoke out against mining because of: "the consequences of opening a mine near our ejido, because it pollutes the environment" (Defiende la Sierra, 2016)

In SubVersiones (2016), the anonymous testimony of a peasant from the municipality of Temixco, Morelos mentioned:

"Well the people have played the game the mining enterprise wants, as they say, it is using that policy that says divide and you shall prevail, and it has been dividing the town, in some cases even families, one family after another it has divided them. So it has committed a massacre to the social fabric, that is how we see it and that is why we are against it and will continue to be against it, until it gets to where it gets, we have spoken out with anger and dignity."

The empirical evidence presented previously for the Mexican case is connected with Machado's (2014) argument in the sense that:

"The new accumulation cycle due to dispossession comes hand by hand with a new model of extractive industries where large scale exploitations substantially modify the equation of impacts on populations, the environment and territories. [...] to prospect, explore, test, exploit, dig, explode, fly, extract, triturate, grind, lixiviate, export: verbs of modern mining illustrate the colonial enterprise."

These verbs which illustrate the mining industry are kept in the productive and economy dimensions, other verbs considering the ecological and social dimensions should be considered, such as criminalize, deprive, commercialize, overexploit and violate.

Taking into consideration that collective acts of resistance recently implemented in some countries of Latin America and extended to Mexico against the hegemonic economic model, postulate the defense of human rights and natural resources contained
70 mil y 80 mil toneladas de cerro de roca al día, se pretende desaparecer un kilómetro de montañas y al final del proyecto que dura nada más nueve años, es un proyecto a nueve años, lo que va a quedar es un tajo de kilómetro y medio de diámetro por 300 metros de profundidad. Entonces, además de las casi 500 hectáreas de depredación de zonas que implican tierras del ejido Cerro de San Pedro. [...] símbolo del estado de San Luis Potosí a partir de 1824. "

En Medio Ambiente y Sociedad (2012), se recabó el testimonio de Mario Martínez, integrante de la Red Mexicana de Afectados por la Minería y del Frente Amplio Opositor a la Minera San Xavier, quien mencionó:

"Se cambió el Artículo 27 Constitucional. [...] Esa fue la entrada para poder entrar al Tratado de Libre Comercio. El Tratado de Libre Comercio se firmó en el 1994 y en el 1995 empiezan a entrar las mineras. Si tú ves, el Secretario de Economía ha ido al extranjero, ha ido a China a ofrecer nuestro país, a decirle a los chinos vayan a México a invertir, tenemos como sabe que China es una potencia industrial, y que requiere de gran cantidad de minerales, pues van hasta allá. Vayan a México, ahí tenemos nuestro país el $70 \%$ está mineralizado, les damos todas las facilidades, las empresas no pagan impuestos aquí en México. Pues hacen labor social, lo que ellos llaman responsabilidad social empresarial, o sea que, en vez de pagar impuestos, pues pintan la iglesia, pavimentan un tramito de carretera, regalan una o dos computadoras a una escuela, el día de las madres hacen un festival, les dan una canastita, una bolsa con una despensa. Son las políticas de nuestro país, las políticas entreguistas de nuestro país que están entregando nuestro territorio, están entregando nuestra economía, están entregando todo para beneficio de los pequeños grupos de poder empresariales."

En Movimiento M4 (2016), se presentó el testimonio de Esperanza Salazar, Coordinadora del colectivo Bios Iguana, Colima:

"La comunidad indígena de Zacualpan [...] tiene una gran riqueza biológica [...] y además cuenta con un ojo de agua, de donde abastece a la comunidad [...] sino también a dos ciudades que están en Colima y Villa de Álvarez, en su totalidad 
in the territory, to more radical positions in favor of sustainability. ${ }^{5}$

Therefore, it is necessary to concretize the dialogues of wisdom built within the academy and the scientific knowledge with civil society organizations who undertake collective actions of resistance against mining megaprojects.

To jointly review if it is convenient to keep the extractivism model in the mining industry for the national development as it is being currently practiced affecting nature and human rights; or, would it be enough to move towards the neo-extractivism model through which the Mexican State can get a more honest distribution of the mining lease.

Meanwhile, another possibility would consist on checking the feasibility of advancing towards a postextractivism model where human an nature rights are respected. ${ }^{6}$

Based on the aforementioned information, in a future perspective, the need to socially build other possible forms of mining is raised, especially those that mitigate environmental destruction and respect human rights of indigenous and peasant peoples, as it happens, for example, with Canadian mines in their own country.

It would be desirable if this took place while, according to Torres (2015), an eco-social model that surpasses sustainable development is built, where peace, social justice and human rights are in the center, in a nature-society harmony that could stop the socio-environmental devastation that causes

\footnotetext{
${ }^{5}$ According to Svampa (2017), they reject extractive megaprojects to avoid jeopardizing the right to life of future generations. Radical standpoints that in Mexico rise from organizations of the civil society formed as collective subjects such as the Asamblea Nacional de Afectados Ambientales, the Frente Amplio Opositor a Minera San Xavier and the Red Mexicana de Afectados por la Minería (REMA). Since 2008 the latter has carried out collective acts of resistance against mining megaprojects...

${ }^{5}$ (cont.) ....and has recently reiterated its critique to this extractive model that has accompanied Mexico for 36 years, and as a collective subject it did so by setting its position against the initiative to reform the Mining Law presented on October, 2018 in the Senado de la Republica. Especially because according to REMA the original terms proposed in that initiative, would contribute to accelerate the territorial dispossession and destruction of natural resources (REMA, 2018).

${ }^{6} \mathrm{As}$ Svampa pointed out (2017) with post-developmental alternatives, recalling what Gudynas (2012) proposed, in regard to designing and implementing public policies that would put in the middle the social debt and the environmental debt. Where sustainability appears as a transverse element of public policies, which according to Svampa (2017) are necessary:
}

son unas 300000 personas. La mina que se intenta instalar o explotar [...] es una mina de oro, plata y cobre, esto significa que se van a utilizar grandes cantidades de sustancias químicas como cianuro, y también significa que se va a sacar una gran cantidad de piedra del subsuelo, y esto el contacto del agua con el aire y estas sustancias libera otras sustancias como metales pesados, esto es una de las principales contaminaciones."

En relación con las afectaciones a este tipo de derechos, Jesús Alfonso Ochoa, defensor de comunidades libres de minería en el estado de Chiapas, de acuerdo con OCMAL (2015), señaló que:

"el problema es aún más grave cuando no solamente

el Gobierno Federal y el Estatal otorgan el pase directo a las empresas mineras para que destruyan lo que queda de Chiapas. Sino que permiten 'casi de forma clandestina', la extracción de titanio en minas ubicadas en regiones de alta biodiversidad, bosques y fuentes de agua de las Áreas Naturales Protegidas de Chiapas."

Tal y como lo señaló Florilia Cruz del Ejido Ovando Turquía, municipio de Esquintla, Chiapas, en el año 2015, quien se manifestó en contra de la minería por las: "consecuencias de la apertura de la mina cerca en nuestro ejido, ya que contamina el medio ambiente" (Defiende la Sierra, 2016).

En SubVersiones (2016), el testimonio anónimo de un campesino del municipio de Temixco, Morelos, mencionó:

"Pues la gente se ha prestado a jugar el juego que la minera quiere, que es como dicen, está usando esa política que dicen que divide y vencerás. $Y$ ha estado dividiendo al pueblo, en algunos casos hasta familias, familia por familia las ha dividido. Entonces ha cometido una masacre al tejido social, así lo consideramos nosotros y es por lo que, nosotros nos oponemos y nos vamos a seguir oponiendo, hasta que tope en lo que tope, lo hemos manifestado con coraje y dignidad."

La evidencia empírica presentada anteriormente para el caso mexicano se conecta con el argumento de Machado (2014) en el sentido de que:

"El nuevo ciclo de acumulación por despojo viene de la mano de un nuevo modelo de industrias extractivas donde la escala gigantesca de las explotaciones modifica sustancialmente la ecuación 
climate change, because it has been shown that megaprojects undertaken by enterprises certified as sustainable, destroy natural resources and the cultural patrimony of indigenous peoples (Torres, 2017).

\section{Outline of public policy guidelines about mega-mining and human rights}

A set of federal and state guidelines are shown hereunder as statements divided in four categories of human rights, which before they are designed and implemented can be collectively discussed with participation from the population along with civil society organizations, academic institutions, government dependencies and enterprises to socially built another form of carrying out the mining activity in Mexico with a human rights approach.

\section{Civil rights}

1. Promote collaboration networks with national and international civil society organizations toward collective actions in territories intervened by mega-mining, mainly in defense of civil rights such as the right to life and security.

\section{Political rights}

2. Integrate in the legislative agenda a detailed study concluding in a comprehensive reform of the Mining Law, so the accomplishment of human rights and collective rights linked to natural resources, mainly water, land and air are strengthened in Mexico, to avoid intervention in territories designed as Natural Protected Areas.

3. Promote a national enquiry about the participation of the mining industry in the National Development Project for the current political transformation in Mexico, open to participation of all the Mexican citizens registered in the electoral roll and organized by the Instituto Nacional Electoral.

\footnotetext{
${ }^{6}$ (Cont.)... "to go from a "predator extractivist" to a "sensible extractivist", understanding the latter "as the one where social and environmental rules of each country are thoroughly fulfilled, under effective and rigorous inspections and where the impacts are internalized (Gudynas, 2011). [...] The transition is stressed on strategic planning and control of natural goods by the State, reducing export dependency. The second phase should focus on essential extractive activities, meaning those ventures directed towards covering national and regional necessities".
}

de los impactos sobre las poblaciones, el ambiente y los territorios. [...] Prospectar, explorar, catear, explotar, excavar, dinamitar, volar, extraer, triturar, moler, lixiviar, exportar: los verbos de la minería moderna dan cuenta de la empresa colonial. "

Dichos verbos que dan cuenta de la industria minera se quedan en las dimensiones productiva y económica, se deberían considerar otros verbos que atiendan las dimensiones ecológica y social, como criminalizar, despojar, mercantilizar, sobreexplotar y violentar.

Tomando en cuenta que las acciones colectivas de resistencia, implementadas de manera reciente en algunos países de América Latina y por extensión a México, ante el modelo económico hegemónico, postulan la defensa de los derechos humanos y de los recursos naturales contenidos en el territorio, hasta posturas más radicales a favor de la sustentabilidad..$^{5}$

Por ello, resulta necesario que el diálogo de saberes que se construye desde la academia y el conocimiento científico se conecte con las organizaciones de la sociedad civil que emprenden acciones colectivas de resistencia ante los megaproyectos mineros.

Para que conjuntamente se revise si es conveniente para el desarrollo nacional que permanezca el modelo del extractivismo en la industria minera, tal y como se practica actualmente con afectaciones a la naturaleza y los derechos humanos. $\mathrm{O}$ en su caso, sería suficiente con transitar hacia la modalidad de neoextractivismo mediante el cual el Estado mexicano consiga una distribución más justa de la renta minera.

Mientras que otra posibilidad consistiría en revisar qué tan factible sería avanzar en la industria

\footnotetext{
${ }^{5}$ Según Svampa (2017), argumentan la negativa a los megaproyectos extractivos para evitar que se hipoteque el derecho a la vida de las futuras generaciones. Posturas radicales que en México surgen desde organizaciones de la sociedad civil integradas como sujetos colectivos como la Asamblea Nacional de Afectados Ambientales, el Frente Amplio Opositor a Minera San Xavier y la Red Mexicana de Afectados por la Minería (REMA). Esta última, que desde el año 2008 ha realizado acciones colectivas de resistencia frente a los megaproyectos mineros y que de manera reciente reiteró su crítica a este modelo extractivo que ha acompañado a México durante los últimos 36 años, y como sujeto colectivo lo hizo al fijar su postura frente a la iniciativa de reforma a la Ley Minera presentada en octubre de 2018 en el Senado de la República. Sobre todo, porque según REMA dicha iniciativa en los términos originalmente planteados contribuiría a acelerar el despojo territorial y destrucción de los recursos naturales, (REMA, 2018).
} 
4. Encourage public programs oriented towards prevention of the internal forced displacement process, which contemplates a ruling by citizens as result of a previous and informed public enquiry to authorize mining mega-projects.

5. Promote a citizen rogatory so the Congreso de la Unión instructs the Mexican government to incorporate through the Instituto Nacional de Estadistica y Geografía (INEGI) an official statistical number of Mexicans in an internal forced displacement situation.

6. Make public consultations about the economic and socio-environmental advantages and disadvantages of implementing the Environmental Responsibility Tax (State Ecological Tax) promoted by the government of the state of Zacatecas, to replicate it in the local legislation of other entities with mines.

\section{Social, economic and cultural rights}

7. Propose reforms and additions to the guidelines of the Fondo para el Desarrollo de Zonas de Producción Minera, corresponding to the 2020 fiscal year and subsequent years, that consider science, technology, innovation and development projects in benefit of mining communities, mainly about economic, social and cultural rights, paying special attention to food and public health.

\section{Solidarity or indigenous peoples rights}

8. Promote scientific research about mining by creating an area of mining technological innovation ascribed to the Sistema de Centros Públicos of CONACYT.

9. Manage the installation of citizen monitoring of the violation of constitutional rights and human rights made by the mining industry at a subnational level in Mexico.

10. Encourage reforms to the current Ley General de Transparencia y Acceso a la Información Pública, to strengthen the human right to open public information available in the Plataforma Nacional de Transparencia.

\section{Conclusions}

The relevance of the mining industry in Mexico's development during the neoliberal period has signified an economic benefit for national an minera hacia un modelo de postextractivismo en donde se respeten los derechos humanos y los derechos de la naturaleza. ${ }^{6}$

A partir de lo anterior, en perspectiva de futuro se plantea la necesidad de construir socialmente otras formas posibles de minería, sobre todo, aquéllas que mitiguen la destrucción ambiental y respeten los derechos humanos de los pueblos originarios indígenas y campesinos, como ocurre, por ejemplo, con la manera en que operan las mineras canadienses en su propio país.

Lo anterior sería deseable que ocurriera mientras se construye según Torres (2015), un modelo ecosocial para una nueva civilización que sobrepase el desarrollo sustentable, donde la paz, la justicia social y los derechos humanos estén en el centro, en una armonía naturaleza-sociedad, que permita detener la devastación socioambiental que ocasiona el cambio climático. Porque se ha evidenciado que los megaproyectos que emprenden empresas certificadas como sustentables destruyen los recursos naturales y el patrimonio cultural de los pueblos originarios (Torres, 2017).

\section{Esbozo de lineamientos de política pública sobre megaminería y derechos humanos}

A continuación, se presenta de manera enunciativa un conjunto de lineamientos de alcance federal y estatal, divididos en cuatro categorías de derechos humanos, que previo a su diseño y aplicación, pueden discutirse colectivamente con participación popular, acompañada de organizaciones de la sociedad civil, instituciones académicas, dependencias de gobierno y las empresas, para construir socialmente otra forma de hacer minería en México con enfoque de derechos humanos.

${ }^{6}$ Como señaló Svampa (2017), con alternativas posdesarrollistas, recuperando lo que planteó Gudynas (2012), en el sentido de diseñar e instrumentar políticas públicas que pongan en el centro la deuda social y la deuda ambiental. En el que aparezca la sustentabilidad como elemento transversal de las políticas públicas, que según Svampa (2017), es necesario: "para pasar de un "extractivismo depredador" a un "extractivismo sensato", entendiendo éste "como aquél donde se cumple cabalmente con las normas sociales y ambientales de cada país, bajo controles efectivos y rigurosos y donde se internalizan los impactos (Gudynas, 2011). [... ] La transición coloca el acento en la planificación estratégica y en el control de los bienes naturales por parte del Estado, reduciendo la dependencia exportadora. La segunda fase debiera enfocarse en las actividades extractivas esenciales, esto es, en aquellos emprendimientos que apunten a cubrir necesidades nacionales y regionales." 
transnational enterprises by linking with other productive sectors, especially those connected with foreign markets, either by providing minerals to other sectors of the industry and by acquiring goods, supplies and services to carry out the process of extraction and refinement of minerals. However, socio environmental impacts and violation of human rights in communities of mining territories have been permanently present.

Taking into consideration that the activity carried out by extractive mining will continue its course during the next decades, because of the legal support that assists it as well as the corporate and public interests that support it. It is necessary to stop along the way to give access to a national dialogue that could take us from the diagnose to the proposal, that could put at the center the mega-mining nexus and another possible development; which, although its contribution to economy is small, its socio environmental impacts are high instead.

In a key political moment for Mexico as the one lived with the entrance of the new Federal government in December, 2018 through which we can give a step forward to get out of the prevailing export extractive model, to go towards at least one neo-extractive socio environmental national development project that can enable a better distribution of the mining lease in benefit of the intervened communities and where all mining corporates get environmental certifications becomes a common practice

For that purpose, collective proposals and actions with incidence in legal reforms, design and execution of programs and public budgets will be of great value, for which, the necessary ingredient would imply active academic intervention and that of organizations of the civil society, as well as the communities directly and indirectly affected, configured as a social power with the capacity to dialogue with government decision makers and transnational private capital.

It would be desirable to attain the above mentioned to establish diagnose and proposal meetings towards a different way form of carrying out mining activities in Mexico, that will be practiced in fulfillment of the environmental and human rights

\section{Derechos civiles}

1. Promover redes de colaboración con organizaciones de la sociedad civil nacional e internacional hacia acciones colectivas en territorios intervenidos por la megaminería, principalmente para la defensa de derechos civiles como el derecho a la vida y a la seguridad.

\section{Derechos políticos}

2. Proponer en la agenda legislativa un estudio minucioso que culmine en una reforma integral a la Ley Minera, para que en México se refuerce el cumplimiento de los derechos humanos y derechos colectivos ligados a los recursos naturales, principalmente agua, tierra y aire, para evitar la intervención de territorios considerados Área Natural Protegida.

3. Promover una consulta pública nacional sobre la participación de la industria minera en el Proyecto de Desarrollo Nacional para la actual transformación política de México, abierta a la participación de todos los ciudadanos mexicanos inscritos en el padrón electoral vigente y que sea organizada por el Instituto Nacional Electoral.

4. Impulsar programas públicos orientados a la prevención del proceso de desplazamiento forzado interno, que contemple la figura de un dictamen ciudadano derivado de la consulta pública previa e informada para autorizar megaproyectos mineros.

5. Promover un exhorto ciudadano para que el Congreso de la Unión instruya al gobierno de México, para que a través del Instituto Nacional de Estadística y Geografía (INEGI), en la generación de información socioeconómica incorpore una estadística oficial sobre el número de mexicanos en situación de desplazamiento forzado interno.

6. Realizar acciones de consulta pública sobre las ventajas y desventajas económicas y socioambientales de instrumentar el Impuesto de Responsabilidad Ambiental (Impuesto Ecológico Estatal) que promovió el gobierno del estado de Zacatecas, para replicarlo en la legislación local de otras entidades con presencia de minería. 
legislation with the international standards, as it is practiced in tasks of exploration, development, exploitation and mine closure in territories of developed economies.

It would also be desirable to start collective actions supporting communities affected by megamining, to recognize the outstanding cases of community organization for stopping extractive mega-projects or encouraging legal fights and modifications to the local legislation to stop changing the land use for mining megaprojects, this entails a socio economic perspective.

It is also relevant to recognize this type of experiences from testimonies of affected citizens or collectives who are organized for resistance, because they have not only contributed to stop depredator projects of exploration or exploitation that have already begun their activity, but they have done it through a prevention and restauration perspective that can help inform communities that in the future they would be affected by the more than 25 thousand concessions that the Mexican Government authorized and are currently in force.

Some of those outstanding cases have been Baja California Sur, Chiapas, the municipalities of Tapachula, Huehuetán, Mazatán, Suchiapa, Tuxtla, Acacoyagua, Escuintla, Cintalapa, Tonalá and Soconusco; in Chiuhuahua, the ejido Benito Juarez; in Colima, Zacualpan, Comala and las Canoas; in Morelos, Xochitepec and Temixco; in Oaxaca, the municipalities of Calpulálpam, Ejutla de Crespo, Itsmo de Tehuantepec, Ixtepec, Ocotlán de Morelos and Tlacolula de Matamoros; in Puebla, Cuetzalan de Progreso and Ixtacamaxtitlán; in San Luis Potosi, Catorce, Cerro San Pedro and Wirikuta; in Veracruz, Alto Lucero de Gutiérrez Barrios and Actopan.

Collective work in defense of human rights and sustainability of all kind of forms of life for current and future generations has been carried out, staring with the autonomy self-sufficiency-sovereignty-food security, the human right to water and life as well as compatibility with the right to preservation of ecosystems and communities.

End of English version
Derechos sociales, económicos y culturales

7. Plantear reformas y adiciones a los lineamientos del Fondo para el Desarrollo de Zonas de Producción Minera, correspondiente al ejercicio fiscal 2020 y posteriores, que contemplen proyectos de ciencia, tecnología, innovación y desarrollo, en beneficio de las comunidades mineras, principalmente sobre derechos económicos, sociales y culturales, con especial atención en la salud pública y alimentación.

\section{Derechos de solidaridad o de los pueblos}

8. Promover la investigación científica sobre minería, a partir de la creación de un área de innovación tecnológica minera adscrita al Sistema de Centros Públicos del CONACYT.

9. Gestionar la instalación de una estación de monitoreo ciudadano sobre la violación a las garantías individuales y derechos humanos, ocasionada por la industria minera a nivel subnacional en México.

10. Fomentar reformas a la Ley General de Transparencia y Acceso a la Información Pública vigente, para fortalecer el derecho humano a información pública de oficio sobre el sector minero, disponible en la Plataforma Nacional de Transparencia.

\section{Conclusiones}

La relevancia de la industria minera en el desarrollo de México durante el periodo neoliberal ha significado un beneficio económico para las empresas transnacionales y nacionales al vincularse con otros sectores productivos, principalmente aquéllos conectados con el mercado exterior, ya sea al proveer minerales a otros sectores de la industria y al adquirir bienes, insumos y servicios para llevar a cabo los procesos de extracción y beneficio de minerales. Sin embargo, los impactos socioambientales y la violación a los derechos humanos en las comunidades de los territorios mineros, se ha presentado de manera permanente.

Considerando que la actividad realizada por la minería extractiva seguirá su curso durante las próximas décadas, tanto por el soporte legal que le asiste, como por los intereses corporativos y públicos 


\section{References / Referencias}

Azamar A., A. (2016). Acumulación originaria: explotación laboral y generación de ganancia en la Minería de México. Tesis doctoral en Economía Internacional y Desarrollo, Facultad de Ciencias Económicas y Empresariales, Universidad Complutense de Madrid, Madrid, España. 262 pp. Publicación en línea, disponible en internet en el sitio: https://eprints.ucm.es/40577/ [con acceso el 1511-2018].

Bellota, L. (2017). “La megaminería en México: devastación ecológica y despojo territorial". Centro de Estudios Sociales y de Opinión Pública. Cámara de Diputados. LXIII Legislatura. Ciudad de México, México. Publicación en línea, disponible en internet en el sitio: https://bit. ly/2uy8447 [con acceso el 10-09-2018].

Boni A. F. (2014). Minería, conservación y derechos indígenas. Territorio y conflicto en Catorce, San Luis Potosí. Tesis de Doctor en Geografía, Posgrado en Geografía, Facultad de Filosofía y Letras, Centro de Investigaciones en Geografía Ambiental, Universidad Nacional Autónoma de México. 188 pp.

Burnes O., A. (2006). El drama de la minería mexicana. Del pacto colonial a la globalización contemporánea. Coordinación de Investigación y Posgrado. Universidad Autónoma de Zacatecas. Zacatecas. México.

Cárdenas, J. (2013). “La Minería en México: Despojo a la nación". Revista Mexicana de Derecho Constitucional. Núm. 28, enero-junio:36-73.

Casado, J. M., \& Sánchez, M. T. (2019). “Los mineros en el México neoliberal." Investigaciones Geográficas, Universidad Nacional Autónoma de México. Publicación en línea, disponible en internet en el sitio: http://www. scielo.org.mx/pdf/igeo/n98/2448-7279-igeo-98-10.pdf [con acceso el 26-12-2019].

Cortés M., E. (2008). "Criminalización de la protesta social en México." El Cotidiano, vol. 23, no. 150 julio-agosto, pp. 73-76, Universidad Autónoma Metropolitana, Unidad Azcapotzalco, Distrito Federal, México. Publicación en línea, disponible en internet en el sitio: http://www.redalyc. org/articulo.oa?id=32515011 [con acceso el 22-11-2018].

Fundar. Centro de Análisis e Investigación. (2017). Las actividades extractivas en México: Estado actual. Anuario 2016. Publicación en línea, disponible en internet en el sitio: http://fundar.org.mx/mexico/pdf/ Anuario2016corr.pdf [con acceso el 23-07-2018]. que la respaldan. Resulta indispensable hacer un alto en el camino, para dar paso a un diálogo nacional que nos lleve del diagnóstico a la propuesta, que ponga en el centro el nexo megaminería y otro desarrollo posible; que, aunque su contribución a la economía es relativamente baja, sus impactos socioambientales son en cambio muy altos.

En un momento político clave para México como el que se vivió con la entrada en funciones del nuevo gobierno Federal en diciembre de 2018, mediante el cual podamos dar un paso hacia adelante para salir del modelo extractivo exportador prevaleciente. Para transitar por lo menos a un proyecto de desarrollo nacional de corte neoextractivista socioambiental, que permita una mejor distribución de la renta minera, en beneficio de las comunidades intervenidas y donde se vuelva una práctica común que todos los corporativos mineros logren certificaciones ambientales.

Para tal propósito será de gran valía las propuestas y acciones colectivas con incidencia en reformas legales, diseño y ejecución de programas y presupuestos públicos, cuyo ingrediente necesario implique la activa intervención académica y de organizaciones de la sociedad civil, así como las comunidades directa e indirectamente afectadas, configurados como un poder social con capacidad de interlocución con los tomadores de decisiones del ámbito gubernamental y del capital privado transnacional.

Lo anterior sería deseable conseguirlo para el establecimiento de encuentros de diagnóstico y propuestas hacia otra forma de hacer minería en México, que se practique en cumplimiento a la legislación ambiental y de derechos humanos con los estándares internacionales, como se practica en las tareas de exploración, desarrollo, explotación y cierre de minas en los territorios de las economías desarrolladas.

A la par, también sería deseable emprender acciones colectivas, en respaldo de las comunidades afectadas por la megaminería, para darle visibilidad a los casos sobresalientes de organización comunitaria, por frenar megaproyectos extractivos o impulsar la lucha legal y modificaciones a la legislación local, que impidan el cambio de uso del suelo para megaproyectos mineros, esto implica una óptica desde el socio-ecosistema. 
Garibay O., C. (2010). "Paisajes de acumulación minera por desposesión campesina en el México actual". En: Delgado R., G. C. (Coord.). Ecología política de la minería en América Latina. Centro de Investigaciones Interdisciplinarias en Ciencias y Humanidades. UNAM. México. 133-182.

Garibay, C., \& A. Balzaretti. (2009). "Goldcorp y la reciprocidad negativa en el paisaje minero de Mezcala, Guerrero". Desacatos, Revista de Antropología Social. CIESAS. México, Núm. 30, mayo-agosto, pp. 91-110.

Gudynas, E. (2011), "Más allá del nuevo extractivismo: transiciones sostenibles y alternativas de desarrollo" en Veltmeyer, H. (2011), Herramientas para el cambio: Manual para estudios críticos del desarrollo. CIDES-UMSA. Oxfam, La Paz, Bolivia.

Gudynas, E. (2012). "Más allá del desarrollo". En: AAVV, Grupo permanente de trabajo: Alternativa al Desarrollo. Fundación Rosa Luxemburgo, Ecuador.

Gutiérrez R., R. (2010). "Apropiación minera y violación de derechos humanos en México". En: Delgado R., G. C. (Coord.). Ecología política de la minería en América Latina. Centro de Investigaciones Interdisciplinarias en Ciencias y Humanidades. UNAM. México. 281-298.

Guzmán L., F. (2018). Megaminería y 7 maldades del despojo territorial. Editorial Académica Española. Berlín, Alemania.

Guzmán L., F. (2018b). “Acumulación minera por extracción de derechos humanos". Observatorio del Desarrollo. volumen 7, número 20. mayo-agosto, Zacatecas, México.

Harvey, D. (2004). El nuevo imperialismo. Akal. Madrid. España.

Lemus, J. (2018). México a cielo abierto. De cómo el boom minero resquebrajó al país. Grijalbo. Ciudad de México, México.

Machado A., H. (2014). Potosí, el origen. Genealogía de la minería contemporánea, Tiempo. Mardulce. 1ª Edición. Buenos Aires, Argentina.

Patiño, E del R., Espinoza, Ma. de J., \& García, A. (2012). "Concesiones Mineras en Tierras Ejidales: Detrimento de la Propiedad Social". Revista Iberoamericana para la Investigación y el Desarrollo Educativo. Publicación \# 09, julio-diciembre.

Peña, H. (2016). "Desafíos de la seguridad hídrica en América Latina y el Caribe". Serie Recursos Naturales e Infraestructura no. 178. Publicación en línea, disponible en internet en el sitio: https://repositorio.cepal.org/
Además, es relevante darle visibilidad a este tipo de experiencias a partir de los testimonios de ciudadanos afectados o de colectivos que se han organizado para la resistencia, porque no solamente contribuyen a frenar proyectos depredadores de exploración o explotación que ya iniciaron su actividad, sino mediante un enfoque de prevención y restauración, que ayude a informar a las comunidades que en un futuro serían afectadas por las más de 25 mil concesiones que autorizó el Gobierno de México y que aún permanecen vigentes.

Algunos de esos casos sobresalientes han sido en Baja California Sur; en Chiapas, los municipios de Tapachula, Huehuetán, Mazatán, Suchiapa, Tuxtla, Acacoyagua, Escuintla, Cintalapa, Tonalá y Soconusco; en Chihuahua, el ejido Benito Juárez; en Colima, Zacualpan, Comala y Las Canoas; en Morelos, Xochitepec y Temixco; en Oaxaca, los municipios de Calpulálpam, Ejutla de Crespo, Istmo de Tehuantepec, Ixtepec, Ocotlán de Morelos y Tlacolula de Matamoros; en Puebla, Cuetzalan de Progreso e Ixtacamaxtitlán; en San Luis Potosí, Catorce, Cerro San Pedro y Wirikuta; en Veracruz, Alto Lucero de Gutiérrez Barrios y Actopan.

En dichos casos fue donde se ha trabajado colectivamente por la defensa de los derechos humanos y de la sustentabilidad de todas las formas de vida para las actuales y futuras generaciones, comenzando por la autonomía autosuficienciasoberanía-seguridad alimentaria, el derecho humano al agua y a la vida; así como la compatibilidad con el derecho a la preservación de los ecosistemas y comunidades.

Fin de la versión en español

bitstream/handle/11362/40074/1/S1600566_es.pdf [con acceso el 21-11-2018].

Salazar, H., \& Rodríguez, M. (2015). Miradas en el territorio. Cómo mujeres y hombres enfrentan la minería. Aproximaciones a tres comunidades mineras en México. Heinrich Böll Stiftung. México, Centroamérica y el Caribe. Publicación en línea, disponible en internet en el sitio: https://mx.boell.org/sites/default/files/ 
miradas_en_el_territorio_20.01.2016.pdf [con acceso el 02-01-2020].

Santacruz, G., \& Peña, F. J. (2013). "Huella gris y minería: el impacto de extracción de metales en el agua". En Pérez R.; R. Constantino, y H. Dávila coord. 2013. Agua, alimentación y bienestar: La huella hídrica como enfoque integral de gestión del agua en México. UAM- Xochimilco. Distrito Federal, México.

Seoane, J. (2013). “El agua vale más que el oro. Megaminería y movimientos sociales". En Seoane, J.; Taddei, E. y C. Algranati (2013), Extractivismo, despojo y crisis climática. Desafíos para los movimientos sociales y los proyectos emancipatorios de nuestra América. Herramienta Ediciones, Editorial El Colectivo, Grupo de Estudios sobre América Latina y El Caribe. Buenos Aires, Argentina.

Svampa, M. (2017). Del cambio de época al fin de ciclo. Gobiernos progresistas, extractivismo y movimientos sociales en América Latina. Ensayo Edhasa, primera edición. Buenos Aires, Argentina.

Tamayo, L. (2014). "La minería de tajo a cielo abierto en México: una nueva forma de colonialismo". Nómadas, Revista Crítica de Ciencias Sociales y Jurídicas, 44, (2014.4). Publicación en línea, disponible en internet en el sitio: https://revistas.ucm.es/index.php/NOMA/ article/view/49291 [con acceso el 29-12-2019].

Tetreault, D. (2013). “La megaminería en México. Reformas estructurales y resistencia". Letras Verdes, Revista Latinoamericana de Estudios Socioambientales No. 14. Septiembre, Distrito Federal, México. Publicación en línea, disponible en internet en el sitio: http://revistas. flacsoandes.edu.ec/letrasverdes/article/view/1045 [con acceso el 12-08-2018].

Tetreault, D., McCulligh, C, \& Carlos L. (2019). “Introducción. Panorama de conflictos socioambientales y alternativas en México." En Tetreault, D.; McCulligh, C y Carlos L. (Coord.). (2019). Despojo, conflictos socioambientales y alternativas en México. Miguel Ángel Porrúa, Universidad Autónoma de Zacatecas. México. 5-40.

Toledo, V. (2015). Ecocidio en México. La batalla final es por la vida. Prol. de John M. A., Editorial Grijalbo. Ciudad de México, México.

Torres C., G. (2015). Los senderos de la transición civilizatoria. Colección Tlatemoa. Departamento de Sociología Rural, Universidad Autónoma Chapingo. México.

Torres C., G. (2017). Sustentabilidad y compatibilidad. Centro de Investigaciones Interdisciplinarias y Servicio en
Ciencia, Naturaleza y Cultura, Universidad Autónoma Chapingo. México.

Wagner, L. S. (2014). "Conflictos socioambientales. La megaminería en Mendoza 1884-2011". Editorial de la Universidad Nacional de Quilmes, Buenos Aires, Argentina, Publicación en línea, disponible en internet en el sitio: https://dialnet.unirioja.es/servlet/ articulo?codigo=6239252 [con acceso el 30-12-2019].

\section{Hemerografía}

Autoridades Tradicionales y Agrarias del Pueblo Wixárika. (2017). "Pronunciamiento Consejo Regional Wixárika por la Defensa de Wirikuta", febrero, 03. Publicación en línea, disponible en internet en el sitio: http:// consejoregionalwixarika.org/?p=267 [con acceso el 2812-2019].

Bailón, M. J. (s/f.) “Derechos humanos, generaciones de derechos, derechos de minorías y derechos de los pueblos indígenas; algunas consideraciones generales". Publicación en línea, disponible en internet en el sitio: http://www.corteidh.or.cr/tablas/r28614.pdf [con acceso el 30-12-2019].

Bartra, A. (2014). "Campesinos del tercer milenio: aproximaciones a una quimera". Conferencia Inaugural del IX Congreso Latinoamericano de Sociología Rural (ALASRU). Universidad Autónoma MetropolitanaXochimilco, Distrito Federal, México.

Camimex. (s/f.) “Buenas prácticas de desarrollo comunitario en minería". Publicación en línea, disponible en internet en el sitio: https://www.camimex.org.mx/files/3115/0938/7392/ Bpracticas.pdf [con acceso el 12-08-2018].

Camimex. (2018). "Empresas Socialmente Responsables". Publicación en línea, disponible en internet en el sitio:https://www.camimex.org.mx/index.php/ reconocimientos/empresas-socialmente-responsables/ [con acceso el 10-07-2018].

CNDH. (2016). "Informe especial sobre desplazamiento forzado interno (DFI) en México". Ciudad de México, México. Publicación en línea, disponible en internet en el sitio: http://gaceta.diputados.gob.mx/Gaceta/63/2016/ may/Cndh-20160523.pdf [con acceso el 8-08-2018].

CNN en Español. (2007). "Entrevista Aristegui CNN FAO MSX 1 parte de 3". Publicación en línea, disponible en internet en el sitio: https://www.youtube.com/ watch?v=4bGy_h-O-74 [con acceso el 31-12-2019]. 
Consejo Nacional de Evaluación de la Política de Desarrollo Social. (2016). “Resultados de pobreza en México 2016 a nivel nacional y por entidades federativas 2008-2016". Publicación en línea, disponible en internet en el sitio: https://www.coneval.org.mx/Medicion/MP/Paginas/ Pobreza_2016.aspx [con acceso el 15-11-2018].

Defiende la Sierra. (2016). “Ejidos, pueblos y municipios que se han declarado libres de minería tóxica". Publicación en línea, disponible en internet en el sitio: http:// defiendelasierra.org/ejidos-pueblos-y-municipios-quese-han-declarado-libres-de-mineria-toxica/ [con acceso el 04-01-2020].

Enciso A. (2016). "Hay en México 420 conflictos socioambientales: investigador". Periódico La Jornada, pág. 38. Publicación en línea, disponible en internet en el sitio: http://www.jornada.unam.mx/2016/02/10/ sociedad/038n1soc [con acceso el 25-03-2018].

Environmental Justice Organisations, Liabilities and Trade (EJOLT). (2018). "Atlas de Justicia Ambiental". Publicación en línea, disponible en internet en el sitio: http://ejatlas. org/country, [con acceso el 28-11-2018].

Flores N. (2017). “Más de 100 conflictos sociales por minería en México". Publicación en línea, disponible en internet en el sitio: http://www.contralinea.com.mx/archivorevista/2017/05/17/mas-de-100-conflictos-sociales-pormineria-en-mexico/ [con acceso el 29-09-2018].

Geocomunes. (2017). "Amenaza neoliberal a los bienes comunes: Panorama nacional de megaproyectos mineros". Publicación en línea, disponible en internet en el sitio: http:// geocomunes.org/Analisis_PDF/Mineri\%CC\%81a\%20A\%20 lectura [con acceso el 30-12-2018].

Instituto Nacional de Estadística y Geografía. (2018a). “Principales resultados de la Encuesta Intercensal 2018 Estados Unidos Mexicanos". Aguascalientes. México.

Instituto Nacional de Estadística y Geografía. (2018b). "Sistema de Cuentas Nacionales de México. Producto Interno Bruto Trimestral. Año base 2013. Serie del Primer trimestre de 1993 al tercer trimestre de 2018" Aguascalientes. México. Publicación en línea, disponible en internet en el sitio: https://www.inegi.org.mx/app/ tabulados/v3/default.aspx?pr=18\&vr=1\&in=2\&tp=20\&wr $=1 \& \mathrm{cno}=2$ [con acceso el 15-10-2018].

Medio Ambiente y Sociedad. (2012). "Reportaje Saqueo minero del Cerro de San Pedro", Publicación en línea, disponible en internet en el sitio: https://www.youtube. com/watch?v=On_Q-Sjldpo [con acceso el 01-01-2020].
Movimiento M4. (2016). "La resistencia de Zacualpan: serie de videos sobre la defensa del territorio en México", Publicación en línea, disponible en internet en el sitio: https://movimientom4.org/2016/05/la-resistenciade-zacualpan-serie-de-videos-sobre-la-defensa-delterritorio-en-mexico/ [con acceso el 03-01-2020].

Municipios Puebla. (2015). "Declaran territorio libre de minería a Ixtacamaxtitlán". Publicación en línea, disponible en internet en el sitio: http:// municipiospuebla.mx/nota/2015-01-25/interiores/ declarar\%c3\%a1n-territorio-libre-de-miner\%c3\%adaixtacamaxtitl\%c3\%a1n [con acceso el 28-12-2019].

OCMAL. (2015). “Chiapas: Velasco da pase libre a mineras que obtienen 23 mdd al mes, mismas que matan de cáncer a pobladores". Publicación en línea, disponible en internet en el sitio: https://www.ocmal.org/chiapas-velasco-dapase-libre-a-mineras-que-obtienen-23-mdd-al-mesmismas-que-matan-de-cancer-a-pobladores/[con acceso el 29-12-2019].

OCMAL. (2018). "Conflictos mineros en México". Publicación en línea, disponible en internet en el sitio: https:// mapa.conflictosmineros.net/ocmal_db-v2/conflicto/ lista/02024200 [con acceso el 16-11-2018].

Ramírez, E. (2017a). "59 mineras presuntas evasoras de impuestos y obligaciones". Publicación en línea, disponible en internet en el sitio: http://www. contralinea.com.mx/archivo-revista/2017/03/05/59-

mineras-presuntas-evasoras-de-impuestos-yobligaciones/ [con acceso el 29-12-2018].

Ramírez E. (2017b). "Señalan como evasoras fiscales a 12 mineras canadienses". Publicación en línea, disponible en internet en el sitio: http://www.contralinea.com.mx/archivorevista/2017/07/04/senalan-como-evasoras-fiscales-a-12mineras-canadienses/ [con acceso el 30-12-2018].

REMA. (2018). "Comunicado de prensa. Morena adereza la Ley Minera". Publicación en línea, disponible en internet en el sitio: http://www.remamx.org/2018/11/35493/ [con acceso el 24-11-2018].

Ruiz, J. C. (2019). “¿La cuarta transformación o la transformación de cuarta? Continuidades y simulaciones de los megaproyectos neoliberales en el "periodo posneoliberal". XLI Coloquio de Antropología e Historia Regionales, Extraños en su tierra. Sociedades rurales en tiempos del neoliberalismo: escenarios en transición. El Colegio de Michoacán, Michoacán, México. Publicación en línea, disponible en internet en el sitio: 
https://www.colmich.edu.mx/coloquioXLI/miercoles. php [con acceso el 28-12-2019].

Secretaría de Economía. (2015). "Inversión Extranjera Directa en México y en el Mundo". Dirección General de Inversión Extranjera, Distrito Federal, México. Publicación en línea, disponible en internet en el sitio: http://www.economia.gob.mx/files/comunidad_ negocios/ied/analisis_publicaciones/Otros\%20 estudios/carpeta_informacion_estadistica_1115.pdf [con acceso el 24-04-2018].

Secretaría de Economía. (2018). "Informe estadístico sobre el comportamiento de la inversión extranjera directa en México (enero-septiembre de 2018)", Ciudad de México. México. Publicación en línea, disponible en internet en el sitio: https://www.gob.mx/cms/uploads/attachment/ file/413749/Informe_Congreso-2018-3T.PDF [con acceso el 21-11-2018].

Secretaría del Trabajo y Previsión Social. (2018). “Información Laboral". Publicación en línea, disponible en internet en el sitio: http://www.stps.gob.mx/gobmx/estadisticas/pdf/ perfiles/perfil\%20nacional.pdf [con acceso el 21-10-2018].

SEDATU. (2015a). "Impulso al fondo minero y las zonas económicas especiales, para transformar el rostro de la pobreza en México: RRB". Publicación en línea, disponible en internet en el sitio: https://bit.ly/1L78Zb6 [con acceso el 17-07-2018].

SEDATU. (2015b). "Fondo Minero 2015". Publicación en línea, disponible en internet en el sitio: https://bit.ly/2Q6TUB0 [con acceso el 17-07-2018].

SEDATU. (2016). "Fondo Minero 2016". Publicación en línea, disponible en internet en el sitio: https://bit.ly/2U6kRmH [con acceso el 17-07-2018].

Servicio Geológico Mexicano. (2018). Anuario Estadístico de la Minería Mexicana 2017, Edición 2018. Pachuca, Hidalgo. México.

SubVersiones. (2016). "Mina a cielo abierto en la zona de Xochicalco". Publicación en línea, disponible en internet en el sitio: https://www.youtube.com/watch?time_con tinue $=354 \& v=Y J X n p q H z 70 Y \&$ feature $=e m b \_l o g o \quad$ [con acceso el 30-12-2019].

UNAM. (2017). "LAVIDA contra Caballo Blanco: por un Veracruz libre de minería tóxica." Laboratorio de Estudios sobre Empresas Transnacionales. Publicación en línea, disponible en internet en el sitio: http://let.iiec.unam. $\mathrm{mx} /$ node/1346 [con acceso el 30-12-2019]. 
